
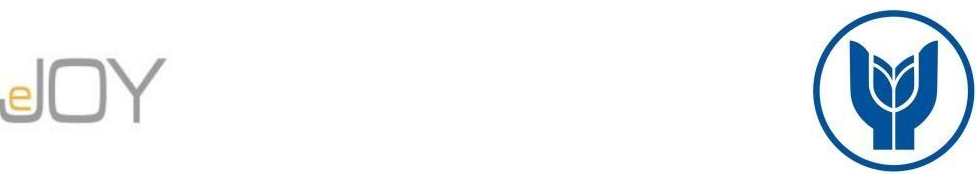

Yeşil, S., Mavi, Y. / Journal of Yasar University, 2021, 16/63, 1078-1104

\title{
Covid-19 Korkusu'nun Duygusal Emek, Çalışan Performansı, İş Tatmini, Yaşam Doyumu Üzerine Etkisi: Bir Alan Araştırması
}

\section{Effect of the Fear of Covid-19 on Emotional Labour, Employee Performance, Job Satisfaction, Life Satisfaction: A Field Study}

\author{
Salih YEŞILL, Kahramanmaraş Sütçü İmam Üniversitesi, Türkiye, syes66@ hotmail.com \\ Orcid No: 0000-0003-3237-2258
}

Yüksel MAVI, Kahramanmaraş Sütçü İmam Üniversitesi, Türkiye, yuksel4689@ hotmail.com

Orcid No: 0000-0002-9724-7135

\begin{abstract}
Öz: Dünya, son bir yıldır birçok ülkeyi ve bu ülkelerdeki işletmelerde çalışanları da etkisi altına alan covid-19 salginıyla mücadele içerisindedir. Çalışanın örgütlerde çok önemli ve örgütsel yaşamın devamlılı̆̆ iç̧in vazgeçilmez oluşu çalışanl, bu süreçte covid-19 salginiyla fiziksel ve psikolojik yönden daha fazla mücadeleye zorlamaktadır. Bu araştırmanın amacı covid-19 korkusunun duygusal emek, çallşan performansı, iş tatmini ve yaşam doyumu üzerine etkisini tespit etmektir. Araştırmanın örneklemini AVM çalışanları meydana getirmektedir. Araştırma alan çalı̧̧masıyla desteklenmiştir. Araşstırmada nicel araştırma yönteminden faydalanılmıştır. Araştırma verileri anket tekniğiyle toplanmıştır. Araştırma verileri SPSS 25.0 paket programında frekans, güvenirlik, faktör, korelasyon ve regresyon analiziyle test edilmiştir. Analiz sonucunda sosyal faktörlerin yüzeysel davranışı negatif yönde etkilediği görülmüşürr. Psikolojik faktörlerin ise çalışan performansını negatif yönde etkilediği belirlenmiştir. Bu sonuçlar teori ve uygulama bağlamında tartış̧lmıştır.
\end{abstract}

Anahtar Kelimeler: Covid-19 Korkusu, Duygusal Emek, Çalışan Performansı, İ̧̧ Tatmini, Yaşam Doyumu

JEL Sinıflandırmasi: M10, M12, M19

Abstract: The World, has been struggling with the covid-19 epidemic, which has affected many countries and employees in businesses in these countries for the past year. The fact that the employee is very important in organizations and indispensable for the continuity of organizational life forces the employee to struggle more physically and psychologically with the covid-19 epidemic in this process. The aim of this study is to determine the effect of covid-19 fear on emotional labor, employee performance, job satisfaction and life satisfaction. The sample of the study consists of shopping mall employees. The research was supported by a field work. The quantitative research method was used in the research. The research data were collected by questionnaire technique. The research data were analysed by frequency, reliability, factor, correlation, regression analysis in SPSS 25.0 package program. As a result of the analysis, it was seen that social factors affect the superficial behavior negatively. It was determined that psychological factors negatively affect employee performance. These results are discussed in the context of theory and practice.

Keywords: Covid-19 Fear, Emotional Labour, Employee Performance, Job Satisfaction, Life Satisfaction JEL Classification: M10, M12, M19

\section{Giriş}

Covid-19'un, 2020 senesine damgasını vuran olaylardan biri olduğu belirtilmektedir (Duygun, 2020: 233). Covid-19, tıbbi bir olay olmasının yanında gerek toplumu gerekse kişileri birçok düzeyde etkileyen ve çeşitli biçimlerde bozulmalara yol açan sosyal bir olgudur (Yanarates, 2020: 29). Bütün dünyayı hâkimiyetine alan covid-19'un, kesin tedavisine ilişkin belirsizliğinde halen sürdüğü görülmektedir (Gencer, 2020: 1154). Diğer taraftan aşının 
bulunamaması, basında pandemiyle ilgili haberlerin sürekli yer alması, vaka ile ölüm oranlarının an itibariyle artış göstermesi gibi sebeplerde insanları kaygıya düşürmektedir. Bazı insanlarda bu durumun kaygı seviyesini geçerek korkuya dönüşmesi mümkündür (Gencer, 2020: 1154). Bazılarına bakıldığında ise bunların, covid-19 bulaşmış bireylerle temas etme veya hastalığı kapma korkusu yaşayabildikleride görülmektedir (Lin, 2020: 1). Esasında bu endişenin veya korkunun bir dereceye kadar anlaşılabilmesi mümkündür Çünkü hiçbir insanın yüksek ölüm riski bulunan bir virüs ile enfekte olmayı istemesi söz konusu değildir (Kobayashi vd., 2020: 2). Bu bakımdan covid-19 korkusuyla ilgili çalışmaların yapılmasının ve konunun ayrıntılarıyla incelenmesinin alanyazın açısından büyük önem taşıdığı görülmektedir.

Çin'in Wuhan kentinde ortaya çıkan covid-19, ölümcül sonuçları olan bir pandemi olarak nitelendirilmektedir (Ladikli vd., 2020: 71). Salgın ilanının ardından bütün ülkelerin koronavirüsün yayılmasına engel olmak amacıyla birtakım katı önlemler aldıkları belirlenmiştir (Bulut ve Pınar, 2020: 218). Virüsün yayılmasına engel olmak amacıyla alınan birtakım önlemler kapsamında, bireylerin günlük hayatları ani ve beklenmedik biçimde değişime uğramıştır (Duman, 2020: 426). Yaşanılan bu süreç içerisinde insanoğlunun hayatına ateş ölçümü, sosyal mesafe, maske, karantina, dezenfektan ve izolasyon gibi uygulamaların girdiği görülmüştür (Kılıç vd., 2020: 564). Başta sınırların uçuşlara kapatılması, şehirlerarası ulaşıma yasakların getirilmesi, karantina uygulamalarının gerçekleştirilmesi, ohal uygulamalarının yapılması, seyahatlere kısıtlamaların konulması, alış-veriş merkezi, otel, restoran gibi insan etkileşiminin fazla olduğu noktaların kapatılması bunlardan bazılardır (Aydın ve Doğan, 2020: $105)$.

Çin’de ortaya çıkarak hızlı bir şekilde dünyaya yayılan virüsün yalnızca birey sağlığı değil neredeyse ekonomik ve sosyal yaşamın tamamını hâkimiyetine aldığı görülmüştür (Bulut ve Pınar, 2020: 217). İlk defa Çin'de görülen ve dünya üzerindeki bütün kıtalara yayılan pandeminin, demografik yapı ve gelişmişlik seviyelerine göre her ülkeye farklı boyutlarda etkisi olmuştur (Ek vd., 2020: 35). Neredeyse tüm ülkeleri hâkimiyetine alan salgının birçok hastalık, ölüm ve ekonomik kayıplar meydana getirdiği görülmekte ve bu durum halen sürmektedir (Özdemir, 2020: 547). Bu kriz sürecini iyi bir şekilde yönetebilmek amaciyla ülkeler gayret göstermektedirler (Binbaşıŏlu, 2020: 73). Virüsün yayılmasının önüne geçmede hükümetlerce alınan önlemler ekonomiyi olumsuz etkilemiş̧tir (Bulut ve Pınar, 2020: 217). Pandeminin yayılmasını engellemek için alınan önlemler sonucunda üretim hacmi daralmıştır. $\mathrm{Bu}$ durum ise arzın düşmesine yol açmıştır. Çalışma yaşamına ilişkin alınan önlemler üretimi düşürürken, dünyadaki milyonlarca bireyin işinden olmasıyla yani gelir kaybına uğramalarıyla 
sonuçlanmıştır (Bulut ve Pınar, 2020: 223). Bu tarz kısıtlamalar yüzünden birçok kurum faaliyetini kısmi ya da tam olarak durdurmaya mecbur kalmıştır (Aykaç ve Murat, 2020: 95).

Alanyazın incelendiğinde araştırmacıların covid-19 konulu çalışmalar üzerinde yoğunlaştıkları görülmüştür. Bunların içerisinde ise covid-19 korkusuyla ilgili çalışmaların sayıca azlığı dikkat çekmektedir. Sosyal medyada geçirilen zamanın covid-19 korkusu üzerine etkisini ele alan Özdemir ve Arpacığlu (2020: 375-376) ve covid-19 korkusunun belirsizliğe tahammülsüzlüğe etkisini inceleyen Duman (2020: 432-433)'nin çalışmaları bunlardan bazılarıdır. Bu alan araştırmasında da covid-19 korkusu üzerinde önemle durulmuştur. Çalışmanın amacı covid-19 korkusunun duygusal emek, çalışan performansı, iş tatmini ve yaşam doyumu üzerine etkisini tespit etmektir. Araştırma kapsamında covid-19 korkusu, duygusal emek, çalışan performansı, iş tatmini ve yaşam doyumu ele alınmıştır. Yazında bu konuların birlikte ele alındığı herhangi bir araştırmaya rastlanılamamıştır. Böyle bir araştırmanın AVM çalışanlarına uygulanmadığı da görülmüştür. Bütün bunların araştırmayı literatürde özgün kılması açısından önemli olduğu düşünülmüştür.

$\mathrm{Bu}$ alan araştırmasında öncelikle teorik çerçeveye ayrıntılı olarak yer verilmiştir. Sonrasında araştırmanın metodolojisi açıklanmaya çalışılmıştır. Araştırmada birtakım istatistiki analizler yapılmış ve bu analizlerin bulguları yorumlanmıştır. En son olarak ise araştırma sonuç ve tartışmayla bölümüyle bitirilmiştir.

\section{Teorik Çerçeve}

Bu bölümde covid-19 korkusu, duygusal emek, çalışan performansı, iş tatmini, yaşam doyumu konularına yer verilmiş ve ilgili konular ayrıntılarıyla açıklanmıştır.

\subsection{Covid-19 Korkusu}

Dünya tarihine bakıldığında çok sayıda salgın hastalığın mevcut olduğu görülmektedir (Günay Aktaş, 2020: 109). 2020 senesinde içinde yaşadığımız dünya çok ağır etkileri bulunan bir pandemiyle karşılaşmıştır (Binbaşığlu, 2020: 73). Çin'in Wuhan kentinde ilk defa ortaya çıkan bu salgın (covid-19), hızla yayılmış ve dünya üzerindeki birçok ülkede yaşamı durma noktasına getirmiştir (Yetgin, 2020: 324). 2019 yılının sonunda başlayıp 2020 yılında dünyaya yayılmış olan bu virüsün, küresel çapta bir kriz meydana getirdiği görülmüştür (Yurdakul vd., 2020: 212). Bu bakımdan covid-19 sonrası insanlarda psiko-somatik, sosyal-duygusal, bilişsel ve davranışlar tepkiler görülmüştür (Çaykuş ve Çaykuş, 2020: 95). Yaşanan söz konusu süreç, bireylerin hayatlarında birtakım değişiklikler yapmalarında etkili olmuştur (Duygun, 2020: 233). Küresel açıdan neredeyse bütün dünya ülkelerini hâkimiyetine alan ve halen tıbbi yönden 
kesin tedavisi bulunamayan bu virüsün etkisinin bir süre daha süreceği bilinmektedir (Barut ve Yerdelen Kaygın, 2020: 68). Bu nedenle neredeyse her alanda çok kritik sorunlar meydana getiren koronavirüsün her açıdan incelenmesi oldukça önemlidir (Paksoy, 2020: 143-144). Araştırmacılar, insanoğlunun hayatı üzerinde bu derece etkili olan virüsle ilgili sosyoloji, sağlık, psikoloji, eğitim gibi alanlarda çalışmalar yürütmektedirler (Paksoy, 2020: 135).

Covid-19 henüz yeni keşfedilen, öncesinde bireylerde tanımlanmamış olan koronavirüsün neden olduğu bulaşıcı bir hastalıktır (Jiang vd., 2020). Ayrıca beklenmeyen yayılma hızı, süreci krize çevirmiş ve birçok ülkeyi önlem ve tedbir almaya yöneltmiştir (Yıldırımvuran vd., 2020: 53). Her ne kadar pandemiye yönelik her ülkenin aldığı önlemler aynı olmasa da, birçok ülkenin aldığg önlemlerin benzer olduğu bilinmektedir. Pandemiden korunmak amacıyla geçmişte benzer pandemiler karşısında uygulanmayan birtakım uygulamalar hayata geçirilmiştir (Aydın ve Doğan, 2020: 105). Birçok hükümetin küreselleşme çağında sınır ötesi mal ile insan hareketlerini durdurduğu görülmüsştür. Bu duruma küreselleşmenin ve seyahat kolaylığının pandeminin bu derece çabuk yayılmasında ana etken olması sebep olmuştur (Niewiadomski, 2020). Pandeminin yayılmasını engellemek için ülkelere giriş-çıkışlara ve turistik faaliyetlere yasaklar konulması, spor yarışmalarının iptal olması, sınır güvenliklerinin artırılması, karantinaların başlatılması, okulların tatil olması gibi birtakım önlemler alınmasına karşın her geçen gün çok sayıda bireyin hayatını yitirmesine karşı konulamamıştır (Şit ve Telek, 2020: 10). Nitekim salgın hastalık dönemlerinde kendini gösteren ve temel duygusal tepkilerden birisi olan korkunun, insan davranışlarındaki değiş̧ikliklerin önemli ölçüde nedeni olduğu ortaya konmuştur (Witte ve Allen, 2000).

Covid-19, ekonomik ve sosyo-psikolojik olmak üzere birçok alanda yıkım meydana getirmiştir (Aydın ve Doğan, 2020: 108). Bunun sonucunda ekonomik ve psikolojik açıdan insanlar çökme derecesine gelmişlerdir (Binbaşıŏlu, 2020: 82). Bu süreçte insanın ve toplumun ruh sağlığının göz ardı edilemeyecek bir konu haline geldiği görülmüştür (Gencer, 2020: 1167). Sosyal ilişkilerin ruh sağlığını korumadaki rolü göz önüne alındığında, salgının yarattığı olumsuz ruhsal etkilerin yaşanması kaçınılmazdır (Bozkurt vd., 2020: 305). Sevdiklerinden ayrı kalmanın, hastalık ile bulaş korkusunun, tecrit ve karantinayla karşı karşıya gelme durumunun, yaşam şartlarında görülen ani değişikliklerin insanlar üzerinde artan bir psikolojik baskıya sebep olması söz konusudur (Elbay vd., 2020). Her ne kadar korku ve bunun yaratmış olduğu birtakım psikolojik durumlar pandemi dönemleri için bir noktaya kadar anlaşılabilir olsa da, pandeminin yarattığı etkileri azaltmada koruyucu müdahale programlarının çeşitlendirilip hayata geçirilmesi ve mevcut uygulamalarında önemle takip edilmesinin gerektiği unutulmamalıdır (Gencer, 2020: 1167). Diğer yandan koronavirüs salgını 
olmadan önce dünya ekonomisi iyileşme yolunda ilerlerken bu salgının yayılmasıyla dünya ekonomisinin ciddi hasar aldığı görülmektedir (Tosunoğlu ve Kasal, 2020: 379). Pandeminin ekonomik etkileri ülkeler ve sektörler arasında önemli derecede hissedilmektedir. Bu durum ise finansal piyasaları olumsuz olarak etkilemiştir (Özdemir, 2020: 547). Ayrıca hizmet odaklı ekonomilerde güçlü bir ekonomik bozulma meydana gelmiştir (Cinel, 2020: 131). Küresel çaptaki işsizlik giderek daha da yükselmiştir (Cinel, 2020: 137).

\subsection{Duygusal Emek}

Örgütlerin devamlılıklarının ve başarılarının çalışanların elinde olduğu bilinmektedir (Kulualp Göktaş ve Sarı, 2018: 1167). Kurumların gelişim ve değişim yolculuklarında işgörenlerin en kritik başarı ölçütleri arasında yer aldıkları görülmektedir. Hizmet sektöründe artan rekabet şartları işgörenlerden beklentileri giderek daha da yükseltmektedir (Güler ve Marşap, 2019: 286). Çalışanların, müşteriyle etkileşimleri sırasında davranışlarını ve duygularını kontrol edebilme ve gösterme biçimleri ciddi bir konu olarak görülmektedir (Hur vd., 2016). Bilhassa müşterilerle birebir etkileşimdeki işgörenler için gerçekleştirilen işin nasıl bir duyguyla yapılacağ1 ve sunulacağı noktasında duygusal emek, işin en kritik unsurudur (Jones, 2001: 283). Nitekim bu konuyla ilgili gerçekleştirilen araştırmalara bakıldığında ise halen eksik kalan araştırma konularının olduğu da dikkat çekmektedir (Wang vd., 2016).

Hochschild'in 1983 yılındaki "Yönetilen Kalpler: İnsan Duygularının Ticarileşmesi” adlı kitabıyla duygusal emek kavramı literatüre girmiştir. Bu kavram "bir ücret karşılığında satılan ve değişim değeri olan, genel olarak gözlemlenebilir yüz (mimik) ve beden gösterimi oluşturmak için duyguların yönetilmesi” şeklinde tanımlanmıştır (Hochschild, 1983: 7). Hochschild, duygusal davranış kurallarının kurum aracılığıyla işgörene aktarıldığını bu duruma uygun olarakta performans değerlendirmeye gidildiğini belirtmiştir. Söz konusu durumun sonucunda işgörenlerde iki tür davranış meydana geldiğini iddia etmiştir (Ünler Öz, 2007). Bunlar derinlemesine davranış ve yüzeysel davranış biçiminde ikiye ayrılmıştır (Mavi, 2016: 10). Kısaca açıklamak gerekirse: yüzeysel davranış boyutu çalışanların örgüt tarafından istenilen duyguları yüz ifadelerinde, jest ile mimiklerinde veya ses tonlarında değişiklik yaparak hissediyormuş gibi yansıtmaları şeklinde ifade edilmektedir (Chu ve Murrman, 2006: 1182). Acil bir duruma müdahale eden kişinin tiksinmesine ya da korkmasına, kendinden emin olmamasına karşın soğukkanlı, kendinden emin, rahat görünüyormuş gibi davranması yüzeysel davranışa verilebilecek örnektir (Yang ve Guy, 2015: 5). Derinlemesine davranış boyutu ise çalışanların beklenen davranışları gerçekten hissedebilmek için kendilerini zorlamaları olarak tanımlanabilir (Diefendorff, vd., 2005: 340). Sosyal hizmet çalışanının çocuk istismarına ilişkin 
bir soruşturma kapsamında bir ebeveyn olarak aynı pozisyonda kendini hayal edip o insanlara daha iyi hizmet sunabilmek için empati kurmaya çalışması derinlemesine davranışa verilebilecek örnektir (Yang ve Guy, 2015: 5).

$\mathrm{Bu}$ konu araştırmacılar tarafından çok incelenmiştir. Ayrıca farklı disiplinler tarafından olumsuz ve olumlu sonuçlarla değerlendirildiği görülmüştür (Kökden Çivit ve Iş1k, 2018: 1218). Her ne kadar üzerinde çok fazla durulmasa da duygusal emeğin neden olduğu olumsuz sonuçların yanında, örgüt ve bireyde bazı olumlu sonuçları da bulunmaktadır (Çoruk, 2014: 82). Duygusal emeğin olumlu etkilerinin olumsuz etkilerine oranla daha az olduğu görülmektedir (Güngör, 2017). Örgüt çalışanının sarf ettiği duygusal emek sonucunda, müşteri memnuniyeti sağlayan kurumun verimliliğinde artış yaşanması mümkün olur (Duman, 2017: 35). Bilhassa performansa dayalı ücretlendirme politikasının uygulandığı bir kurumda çalışanın, kuruma gelen müşterilere göstereceği pozitif duygusal davranışlar doğrultusunda maddi kazancının yükselmesi söz konusu olacaktır (Güngör, 2009: 179). Diğer taraftan ise duygusal emek kavramının organizasyon ile işgören adına olumsuz sonuçları yaşanılan süreç içerisinde ortaya çıkabilir (Brotheridge ve Grandey, 2002: 33).

\section{3. Çalışan Performansı}

Günümüzde rekabet giderek artmakta olup örgütlerin rekabet üstünlüğünü yakalayıp bunu devam ettirmeleri hayati derecede önemlidir. Örgütlerin rekabet üstünlüğü elde edebilmeleri noktasında birtakım unsurların önem kazandığı görülmektedir (Doğan ve Kır, 2018: 9). Bu noktada rekabet ortamında başarı elde etmek isteyen örgütlerin işgörenlerine önem vermeleri gerekmektedir. Ayrıca bu örgütler yüksek performans sergileyen çalışanlara sahip olmalıdırlar (Erdal, 2020: 310). Bir organizasyonun ancak işgörenlerin sergilemiş olduğu performans derecesinde iyi olması mümkündür (Çöl, 2008: 39). Çalışan performansı bir organizasyonun etkililiği, başarısı, performansı yönünden de önem arz etmektedir (Tutar ve Altınöz, 2010). Dolayısıyla çalışanların bireysel performanslarının düşük veya yüksek olmasının, organizasyonların performansını düşüren veya yükselten bir faktör olarak önümüze çıktığı görülmektedir (Aydın vd., 2010: 47). Çalışan performansını yükseltecek ya da performans artışının önüne geçebilecek unsurların neler olduğunun çalışmalara araştırma konusu olduğu görülmektedir (Kesen, 2015: 552). Bireysel beklenti ve örgütsel amaç arasında meydana getirilen ilişkinin sonucu, çalışan performansı olarak nitelendirilmektedir (Tutar ve Altınöz 2010).

Günümüz dünyasına bakıldığında artık her büyüklükteki işletme için işgörenin önemi yadsınamayacak derecede açıktır (Aydın vd., 2010). Örgütlerin belirlemiş oldukları hedeflerine 
ulaşmaları işgören performanslarının fazlalığına bağlıdır (Yılmaz ve Günay, 2020: 92). Diğer taraftan yaşanan gerilimli ilişkilerin örgüt çalışanının psikolojik sağglığını negatif olarak etkilediği ve çalışanın performansının azalmasına yol açtığı görülmektedir (Ülbeği vd., 2019: 1). Psikolojik ve fiziksel yönden rahatsız olan örgüt çalışanının, sadece kendi performansını değil başka işgörenlerin performansını ve sağlığını negatif bir şekilde etkilemesi de mümkündür (Yılmaz ve Günay, 2020: 92). Yine organizasyonların karşılaştıkları en mühim problemlerden biriside performanslarından memnun oldukları işgörenlerinin ya performanslarında zamanla ciddi azalışın yaşanması ya da bunların çalıştıkları işten ayrılmaya meyilli olup bunu zamanla gerçekleştirmeleridir (Diktaş ve Özgeldi, 2020: 11).

\section{4. İş Tatmini}

Bilgi çağının en önemli kaynağı olan insanın, tüm işletmeler tarafından temel girdi olarak kabul edildiği görülmektedir (Ilkım ve Derin, 2018: 242). Örgütlerin gelişmeleri, rekabet avantajı elde etmeleri ve sürekliliklerini korumaları açısından sermaye, teknoloji, kalite vb. unsurların yanında bunları gerçekleştirecek çalışanların önemi göz ardı edilemez (Büyükyılmaz vd., 2019: 19). Örgütlere, gerekli niteliklere sahip olanların alınması ve bunların tatmin edilip verimli olmalarının sağlanması, yöneticilerin başlıca amaçlarından biri haline gelmiştir (Güney, 2007: 37-38). Nitekim kişisel amaçlarını gerçekleştirmek noktasında örgüt çalışanlarının iş ortamında fiziksel, zihinsel, sosyal becerilerini sergiledikleri görülmektedir. Bu süreçte iş ortamı ve iş kaynaklı bireyde duygusal anlamda bazı tepkiler meydana gelir (Yıldız, 2015: 77). İş doyumunu, organizasyonlar açısından önemli konuma getiren iki unsurun mevcut olduğu bilinmektedir. Bunlardan ilki, işgörenlerde iş tatminsizliğinin olması kurumdaki faaliyetlerin bozulmaya başladığını göstermesi şeklindedir (Baltacı vd., 2014: 65). İkincisi de iş tatmini ya da tatminsizliği örgüt çalışanlarının sağlıklarını doğrudan etkilemesi ve örgüt çalışanlarının verimliliklerini yükseltmesi ve düşürmesi biçimindedir (Akşit Aşık, 2010: 32).

Örgütsel davranışın önemli konularından iş doyumunun, yazına motivasyon teorileriyle girdiği görülmüştür (Köroğlu, 2012: 277). İşgörenlerin davranışları ve tutumlarıyla ilgili olarak araştırmacılar, çalışmalar gerçekleştirip iş doyumunun kapsamını belirlemeye çalışmışlardır (Güney, 2007: 37-38). Nitekim iş tatmini tanım olarak, "bir kişinin işyerindeki işe ilişkin deneyimleri ve işe atfettiği değerlerinin yarattığı duygusal hoşnutluk durumudur” (Oshagbemi, 2003: 1210). İş doyumu işkoşullarındaki sorumluluk alanının, iletişim gerekliliklerinin, görevlerin çeşitliliğinin tarafsız bir biçimde değerlendirilmesiyle ilgilidir (Dormann ve Zapf, 2001: 483). Kişinin işine yönelik olumlu algılarının tamamını iş doyumu, olarak görmek mümkündür (Özpehlivan, 2018: 45). Zihinsel olmaktan çok duygusal bir nitelik taşıması da iş 
doyumunun en önemli özelliğidir (İşcan ve Timuroğlu, 2007). Ayrıca iş doyumunun çok boyutlu ya da tek boyutlu olup olmaması da iş doyumu hususunda tartışılanlardan birisidir. İş doyumunun tek boyutlu olmasının, kişinin işinden ötürü ya tatmin duyması ya da tatminsizlik yaşamasını ifade ettiği görülmektedir. Diğer yandan çok boyutlu olması ise kişinin işinden birtakım nedenlerden dolayı tatmin olurken, başka birtakım nedenlerden dolayı tatminsizlik duymasıdır (Aşan ve Özyer, 2008: 138).

Bugünün zorlu ekonomik şartları göz önüne alınırsa, insanların asgari seviyede yaşamları sürdürebilmeleri için vakitlerinin önemli bir kısmını çalıştıkları yerde geçirmeleri gerekmektedir (Kolbaşı ve Bağc1, 2019: 122). Bununla birlikte yaptığı işten doyum sağlayan kişi, işine katkıda bulunma açısından çaba sarf edecektir. Bu birey organizasyonuna yönelik olarakta pozitif duygular besleyecektir (Özpehlivan, 2018: 61). Örgüt çalışanlarının yaptıkları işten doyum sağlaması ve mutluluk duyması, yüksek iş performansının ve iş verimliliğinin önünü açmada etkilidir. Bu ise işgörenlerin örgütüne daha fazla bağlanmasını sağlamaktadır. Örgüt çalışanlarının böylece işte kalma istekleri artış gösterir (Yıldız, 2015: 78). Diğer yandan kişinin her şartta çalıştığı işten mutluluk duyması söz konusu değildir. Bu durumlarında tatminsizlikle sonuçlanması kaçınılmazdır (Demir, 2007: 98). Eğer örgüt çalışanı, tatminsizlik duygusu içindeyse işleriyle ilgili olmayan birtakım durumlarda da kendini mutlu hissedememektedir (Gavcar ve Topaloğlu, 2008). İş doyumu az olan çalışanlarda, bazı olumsuz durumların ortaya çıktığı yapılan araştırmalarda belirlenmiştir (Petrescu ve Simmons, 2008: $654)$.

\subsection{Yaşam Doyumu}

İnsanların ilk zamanlardan itibaren mutlu olmak istedikleri ve mutluluğu oluşturan koşulların ne olduğu üzerinde önemle durdukları görülmüştür (Tuzgöl Dost, 2007). Genellikle kişisel "mutluluk" anlamına gelen yaşam doyumu ekonomik, sosyolojik, psikolojik, kültürel boyutu olan bir kavram şeklinde nitelendirilir (Kirci Çevik ve Korkmaz, 2014: 126). Nitekim pozitif psikolojide mutluluğun terimsel karşılığı olarak çoğunlukla "öznel iyi oluş" kavramının kullanıldı ğı bilinmektedir. Öznel iyi oluş ise birbiriyle ilişkili üç unsuru kapsamaktadır. Bunları yaşam doyumu, olumlu duygulanım ve olumsuz duygulanım olarak ifade etmek mümkündür. Yaşam doyumunun, kişinin hayatına ilişkin bilişsel değerlendirmelerini içerdiği görülmektedir. Olumsuz duygulanımın ve olumlu duygulanımında hoşa giden ve hoşa gitmeyen duygulardan meydana geldiği görülmektedir (Diener ve Suh, 1997). Bir insan hayatından doyum sağladığını dile getiriyorsa bu kişinin sıklıkla olumlu duygular ve az olarak olumsuz duygular yaşadığı belirtilebilir. Ayrıca bu bireyin öznel iyi oluş seviyesinin yüksek olduğunu söylemek 
mümkündür (Diener ve Lucas, 1999). Bu nedenle yaşam doyumu, insanların iyi olma halini ve mutluluğunu kapsamakta olup, ruh sağlığına etkide bulunmaktadır (Diener ve Martin, 2004). Ayrıca yaşam doyumunun halihâzır yaşamdan doyum, gelecekten doyum, yaşamı değiştirme isteği, geçmişten doyum ile bireyin yakınlarının bireyin yaşamı hakkındaki görüşlerini kapsadığı görülmektedir (Dost, 2007: 133). Yaşam doyumunun kişinin çalışma hayatı, boş zamanı ve hayatının başka alanlarıyla da ilgisi bulunmaktadır (Doğan vd., 2015: 1802).

Bir insanın yaşam doyumunu hayatını nasıl değerlendirdiği ve hayatına ne şekilde bakmış olduğu belirler (Pavot vd., 1991). Nitekim hayatın bir anlamı ve yönü bulunduğunu belirtenlerin, optimal seviyede yaşam doyumuna sahip insanlar oldukları söylenmektedir (Keser, 2005). Yaşam doyumu fazla olan insanlara bakıldığında, bunların yaşamlarını değerlendirirken iyi olarak gördükleri alanlarına ağırlık verdikleri belirtilebilir. Fakat yaşam doyumu az olanlara bakıldığında, bunların yaşamlarının kötü olarak gördükleri alanlarına ağırlık verdikleri söylenebilir (Diener vd., 2002). Yine geleceğe dair pozitif beklenti içerisinde olan insanlarında yaşam doyumlarının fazla olduğu ifade edilmektedir (Tuzgöl Dost, 2007). Bu yüzden yaşam doyumu fazla olanların kişilikleri ve benliklerini tanıyan, kendileriyle barışık, duygusal zekâ seviyesi yüksek insanlar oldukları belirtilmektedir (Tümkaya vd., 2008).

\section{Covid-19 Korkusu ile Duygusal Emek, Çalışan Performansı, İş Tatmini, Yaşam Doyumu İlişkisi ve İlgili Hipotezler}

Bugün salgın olarak ilan edilen ve dünyayı hâkimiyetine alan covid-19 virüsünün sebep olduğu hastalığın, insanları ve insanlığı tehdit ettiği ciddi derecede baskı altına aldığ 1 görülmektedir (Çetin ve Anuk, 2020: 184). Virüsün yaşamı tehdit eden bir seyir izlemesiyle dünya üzerindeki birçok ülkenin pandemiyi kontrol altına almak için uyguladıkları kısıtlamalar psikolojik etkilere de sebep olmuştur (Yakut vd., 2020: 255). Covid-19'a henüz çare bulunamamış olması diğer yandan insanların korkuya ve endişeye kapılması yol açmıştır. Artış gösteren bu korkunun, endişeninde insanların davranışlarına yansıdığı görülmüştür (Paksoy, 2020: 135). Bu nedenledir ki salgın hastalıkların yarattığı tehdit algısı yükseldiğinde, panik ve stres yaşayan insanlar olduğundan farklı davranışlar göstermeye başlarlar (Yanarates, 2020: 29). Covid-19 salgınının yarattığı psikolojik etkilerin büyük ölçüde olduğu ifade edilmektedir. $\mathrm{Bu}$ açıdan böyle korkuları değerlendirmenin önemli olduğu vurgulanmaktadır (Pakpour ve Griffiths, 2020). Nitekim insan hayatını bu derece etkileyen covid-19 korkusuyla ilgili yapılan çalışmalara bakıldığında bunların sayıca azlığı dikkat çekmektir. Literatürdeki araştırmalar incelendiğinde Özdemir ve Arpacıoğlu (2020: 376-377), sağlık arama davranışı ile koronavirüs korkusu arasında pozitif yönlü bir ilişki olduğunu tespit etmiştir. Araştırmada sağlık algısı ile 
koronavirüs korkusu arasında ise negatif yönlü bir ilişki görülmüştür. Başka bir çalışmada Duman (2020: 432-433), covid-19 korkusu ile belirsizliğe tahammülsüzlük arasında pozitif yönlü bir ilişki olduğunu belirlemiştir. Araştırmada covid-19 korkusunun ileriye yönelik kayg1 düzeyi ve engelleyici kaygı düzeyi ile arasında pozitif yönlü bir ilişki olduğu da saptanmıştır.

Buradan yola çıkarak araştırmada covid-19 korkusunun duygusal emek, çalışan performansı, iş tatmini ve yaşam doyumunu etkileyeceği varsayımında bulunulmuştur. $\mathrm{Bu}$ araştırmanın hipotezleri aşağıda görüldüğü gibi kurulmaya çalışılmıştır.

H1. Psikolojik faktörler yüzeysel davranışı negatif yönde etkiler.

H2. Psiko-Somatik faktörler yüzeysel davranışı negatif yönde etkiler.

H3. Ekonomik faktörler yüzeysel davranışı negatif yönde etkiler.

H4. Sosyal faktörler yüzeysel davranışı negatif yönde etkiler.

H5. Psikolojik faktörler derinlemesine davranışı negatif yönde etkiler.

H6. Psiko-Somatik faktörler derinlemesine davranışı negatif yönde etkiler.

H7. Ekonomik faktörler derinlemesine davranışı negatif yönde etkiler.

H8. Sosyal faktörler derinlemesine davranışı negatif yönde etkiler.

H9. Psikolojik faktörler çalışan performansını negatif yönde etkiler.

H10. Psiko-Somatik faktörler çalışan performansını negatif yönde etkiler.

H11. Ekonomik faktörler çalışan performansını negatif yönde etkiler.

H12. Sosyal faktörler çalışan performansını negatif yönde etkiler.

H13. Psikolojik faktörler iş tatminini negatif yönde etkiler.

H14. Psiko-Somatik faktörler iş tatminini negatif yönde etkiler.

H15. Ekonomik faktörler iş tatminini negatif yönde etkiler.

H16. Sosyal faktörler iş tatminini negatif yönde etkiler.

H17. Psikolojik faktörler yaşam doyumunu negatif yönde etkiler.

H18. Psiko-Somatik faktörler yaşam doyumunu negatif yönde etkiler.

H19. Ekonomik faktörler yaşam doyumunu negatif yönde etkiler.

H20. Sosyal faktörler yaşam doyumunu negatif yönde etkiler.

\section{Metodoloji}

Bu bölümde araştırmanın amacı ve önemi, kısıtlılıkları, yöntemi, evreni ve örneklemi, ölçekleri, hipotezleri ve modeli, analizlerine yer verilmiştir. Araştırmada yapılan analizlerin sonuçları detaylı bir şekilde sunulmuştur. 


\subsection{Araştırmanın Amacı ve Önemi}

$\mathrm{Bu}$ araştırmada covid-19 korkusunun duygusal emek, çalışan performansı, iş tatmini ve yaşam doyumu üzerine etkisini incelemek amaçlanmıştır. Covid-19 konusuyla ilgili yazında birtakım çalışmaların yapıldığı görülmüştür. Bunların içerisinde ise covid-19 korkusu konulu araştırmaların sayıca az olduğu belirlenmiştir. Buradan hareketle araştırmada covid-19 korkusu, duygusal emek, çalışan performansı, iş tatmini ve yaşam doyumu konuları ele alınmıştır. Araştırma örneklem grubu olarak Kahramanmaraş'taki bir AVM'nin çalışanları seçilmiştir. Nitekim alanyazın incelemesi sonucunda araştırma değişkenlerinin birlikte incelendiği herhangi bir çalışmaya rastlanılamamıştır. Araştırma örneklem grubu olarak ise AVM çalışanları üzerinde böyle bir araştırmanın gerçekleştirilmediği saptanmıştır. Bütün bunların araştırmanın taşıyacağı değer ve yaratacağı özgünlük açısından önem taşıyacağı düşünülmüştür.

\subsection{Araşstırmanın Kisıtlılıkları}

Araştırmanın en büyük kısıtlılığını covid-19 sürecinde yapılması oluşturmuştur. Bu noktada hedeflenen örneklem sayısına ulaşılamamıştır. Dolayısıyla söz konusu durumun araştırmanın önemli kısıtlarının başında geldiğini söylemek gerekir. Covid-19 nedeniyle AVM içerisindeki bazı işletmeler kısmi zamanlı ve tam zamanlı olarak kapanmıştır. Bu durum zamanla AVM çalışanlarının sayısının azalmasında ve işlerini kaybetmelerinde etkili olmuştur. Ayrıca bazı AVM çalışanları iş yüklerinin arttığını belirtip araştırmaya katılmamışlardır. Bazı AVM çalışanları da sosyal mesafe kuralını gözeterek anket formunu doldurmak istememişlerdir. Diğer yandan ülke genelinde konulan yasaklar ve alınan önlemler sebebiyle araştırma hafta içi sabah (10:00) akşam (20:00) arasında gerçekleştirilmiştir. Araştırmanın belli tarihler arasında (Şubat-Mart 2021) uygulanması mümkün olmuştur. Bütün bunların anket formlarının geri dönüş oranını olumsuz etkilemesi kaçınılmaz hale gelmiştir.

\subsection{Araştırmanın Yöntemi, Evreni ve Örneklemi}

$\mathrm{Bu}$ çalışmada, nicel araştırma yönteminden faydalanılmıştır. Araştırma verilerini toplamada anket tekniği kullanılmıştır. Altı bölümden oluşan bir anket formu hazırlanmıştır. Bu anket formunun birinci bölümünde, AVM çalışanlarının sosyo-demografik özelliklerini ölçmek için 7 soru bulunmaktadır. Anket formunun ikinci bölümündeki covid-19 korkusu, üçüncü bölümündeki duygusal emek, dördüncü bölümündeki çalışan performansı, beşinci bölümündeki iş tatmini ve altıncı bölümündeki yaşam doyumuyla ilgili ifadeleri ölçmede 5'li Likert Ölçeği kullanılmıştır. Araştırmanın evreni ve örneklemi konusunda bazı açıklamalar 
yapmanın yararlı olduğu düşünülmektedir. Kahramanmaraş’taki AVM çalışanları üzerinde daha önce böyle bir araştırmanın gerçekleştirilmemesi evrenin seçiminde etkili olmuştur. Nitekim evreni temsil edebilecek örneklem büyüklüğünün tespit edilmesi, araştırma sonuçlarını evrene genelleyebilme adına esas durum niteliğindedir (Ural ve Kılıç, 2006: 40). Bu noktada Sekaran (1992), farklı evren büyüklükleri için kabul edilebilir en az örneklem sayısını belirlemek amacıyla 0,95 güvenirlik ve 0,05 örneklem hatası ile temsil edilebilecek örneklem büyüklüklerini hesaplamıştır. Yapılan hesaplama sonucunda belirlenen değerler aşağıda Tablo 1 'de sunulmuştur.

Tablo 1. Farklı Evrenler İçin Kabul Edilebilir Asgari Örneklem Büyüklükleri (Sekaran, 1992)

\begin{tabular}{|c|c|c|c|c|c|c|c|c|c|c|c|}
\hline $\begin{array}{l}\text { Evren } \\
\text { Büyüklüğü }\end{array}$ & 100 & 500 & 750 & 1000 & 2 bin & 5 bin & $\begin{array}{l}10 \\
\text { bin }\end{array}$ & $\begin{array}{l}20 \\
\text { bin }\end{array}$ & $\begin{array}{l}50 \\
\text { bin }\end{array}$ & $\begin{array}{l}100 \\
\text { bin }\end{array}$ & 1milyon \\
\hline $\begin{array}{l}\text { Örneklem } \\
\text { Say1s1 }\end{array}$ & 79 & 217 & 254 & 278 & 322 & 357 & 370 & 377 & 381 & 383 & 384 \\
\hline
\end{tabular}

\subsection{Araştırmanın Ölçekleri}

Araştırmada kullanılan Covid-19 Korkusu Ölçeği, Duygusal Emek Ölçeği, Çalışan Performansı Ölçeği, İş Tatmini Ölçeği ve Yaşam Doyumu Ölçeği ile ilgili birtakım açıklamalara aşağıda yer verilmiştir.

Covid-19 Korkusu Ölçeği: Araştırmada Arpacı vd. (2020)'nin geliştirdiği güvenirlik ve geçerliği ispatlanmış Covid-19 Korkusu Ölçeği’nden faydalanılmıştır. Covid-19 Korkusu Ölçeği 20 ifade ve 4 alt boyut şeklindedir. Bu ölçeğin psikolojik faktörler alt boyutu 6 ifade, psiko-somatik faktörler alt boyutu 5 ifade, ekonomik faktörler alt boyutu 4 ifade ve sosyal faktörler alt boyutu 5 ifadedir.

Duygusal Emek Ölçeği: Çalışmada Lu ve Guy (2014)'ün Brotheridge ve Lee (2002)'den aldığı güvenirlik ve geçerliği ispatlanmış Duygusal Emek Ölçeği’nden yararlanılmıştır. Duygusal Emek Ölçeği'ndeki yüzeysel davranış alt boyutu 3 ifade ve derinlemesine davranış alt boyutu 3 ifadeden oluşmaktadır.

Çalışan Performansı Ölçeği: Araştırmada Okutan ve Telgilimoğlu (2002)'nin çalışmalarında kullandıkları ölçekten yararlanılmıştır. Ayrıca ölçek Türkmen (2016)'nın çalışmasında da kullanılmıştır.

İş Tatmini Ölçeği: Brayfield ve Rothe (1951), tarafından geliştirilmiştir. Ölçeğin Judge vd. (2000), tarafından 5 ifadelik kısa formu oluşturulmuştur. Ayrıca Bilgin (2019)'un çalışmasında faydalandığı ölçek bu araştırmada da kullanılmıştır. 
Yaşam Doyumu Ölçeği: Araştırmada Diener vd. (1985: 72), tarafından geliştirilen güvenirlik ve geçerliği ispatlanmış Yaşam Doyumu Ölçeği'nden yararlanılmıştır. Yaşam Doyumu Ölçeği, tek boyut ve beş ifadeden meydana gelmektedir.

\subsection{Araştırmanın Hipotezleri ve Modeli}

Covid-19 korkusu ile duygusal emek, çalışan performansı, iş tatmini, yaşam doyumu ilişkisi ve ilgili hipotezler bölümünde araştırmanın hipotezlerine yer verilmiştir. Buradan yola çıkarak covid-19 korkusunun duygusal emek, çalışan performansı, iş tatmini ve yaşam doyumu üzerine etkisi model kurgulanarak aşağıda gösterilmiştir.

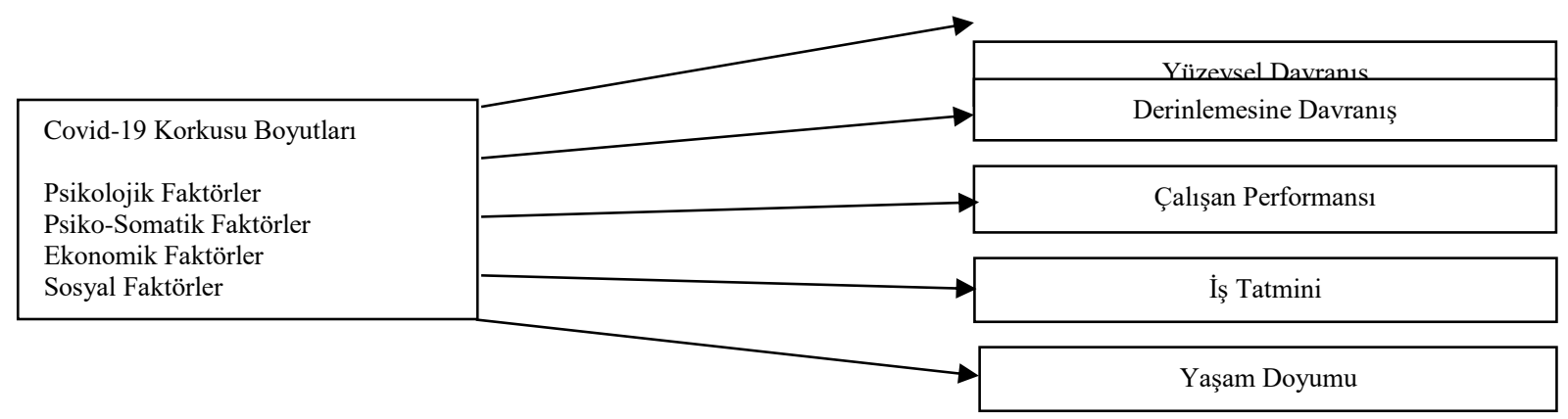

Şekil 1. Araştırma Modeli: Covid-19 Korkusu ile Duygusal Emek, Çalışan Performansı, İş Tatmini, Yaşam Doyumu İlişkisi

\subsection{Araştırmanın Analizleri}

Alan araştırmasının verilerini analiz etmek için SPSS 25.0 programı kullanılmıştır. Araştırma verileri frekans, güvenirlik, faktör, kolerasyon ve regresyon analiziyle test edilmiştir. Araştırma çerçevesinde bu analizlerin sonuçlarına yönelik yorumlara yer verilmiştir.

\section{Araştırmanın Bulguları}

Bu bölümde öncelikle araştırmanın güvenirlik analizi ve faktör analizi yapılmıştır. Sonrasında araştırmanın demografik ve temel bulguları birtakım istatistiki analizlerle test edilmiştir. Araştırma kapsamında bu analizlerin sonuçları sunularak ayrıntılı bir şekilde yorumlanmıştır.

\subsection{Güvenirlik Analizi ve Sonuçları}

Araştırmanın güvenirliği, ölçme yöntemiyle aynı koşullarda tekrar edilen ölçümlerde elde edilen ölçüm değerlerinin kararlılığı şeklinde nitelendirilmektedir (Ercan ve Kan, 2004: 211212). Güvenirlik belirtisi olarak ise güvenirlik katsayısının hesaplanması söz konudur. Bununla birlikte güvenirlik katsayısını hesaplayabilme bağlamında en çok faydalanılan yöntemlerin başında da Cronbach's Alpha katsayısı ( $\alpha$ ) gelmektedir (Güriş ve Astar, 2014: 245). Bu 
araştırmada kullanılan ölçeklerde güvenirlik analiziyle belirlenmiş olup sonuçları Tablo 2'de gösterilmiştir.

Tablo 2. Güvenirlik Analizi ve Sonuçları

\begin{tabular}{|c|c|}
\hline Değişkenler & Cronbach's Alpha $(\alpha)$ \\
\hline Psikolojik Faktörler &, 847 \\
\hline Psiko-Somatik Faktörler &, 959 \\
\hline Ekonomik Faktörler &, 907 \\
\hline Sosyal Faktörler &, 904 \\
\hline Yüzeysel Davranış &, 701 \\
\hline Derinlemesine Davranış &, 867 \\
\hline Çalışan Performansı &, 953 \\
\hline İş Tatmini &, 899 \\
\hline Yaşam Doyumu &, 889 \\
\hline
\end{tabular}

Tablo 2'deki Güvenirlik Analizi Sonuçlarına Göre:

Güvenirlik analizi Cronbach Alpha's $(\alpha)$ değerlerinden; psikolojik faktörler (,847), psikosomatik faktörler (,959), ekonomik faktörler (,907), sosyal faktörler (,904), yüzeysel davranış $(, 701)$, derinlemesine davranış $(, 867)$, çalışan performansı $(, 953)$, iş tatmini $(, 899)$ ve yaşam doyumu (,889) olarak saptanmıştır. Her boyutun iç tutarlılık katsayısının kabul edilebilir en az güvenirlik katsayısı olan ,70’in üzerinde olduğu görülmektedir (Nunnally, 1978). Bu sonuçlar, araştırmada kullanılan ölçeklerin güvenilir düzeyde olduğunu göstermektedir.

\subsection{Faktör Analizi ve Sonuçları}

Yapısal geçerliğin incelenmesinde faydalanılan temel yöntemlerden birinin de faktör analizi olduğu bilinmektedir (Jonsson, 2000: 1457). $\mathrm{Bu}$ analizin (faktör analizi) gerçekleştirilmesindeki temel amaç ise fazla sayıdaki ifadelerin daha az sayıdaki faktörle belirtilmesidir. $\mathrm{Bu}$ analiz sonucunda, ölçülen ifadelerin bir araya toplanıp çeşitli gruplar meydana getirdiği görülür. Her faktör grubunun, içinde yer alan ifadelerin ortak özelliklerine göre belli bir faktör ismiyle ifade edilmesi mümkün olur (Karasar, 2005: 152). Bu araştırmada kullanılan ölçeklere ilişkin faktör analizi ve sonuçları aşağıda Tablo 3 ve Tablo 4'te gösterilmiştir. 
Tablo 3. Faktör Analizi ve Sonuçları

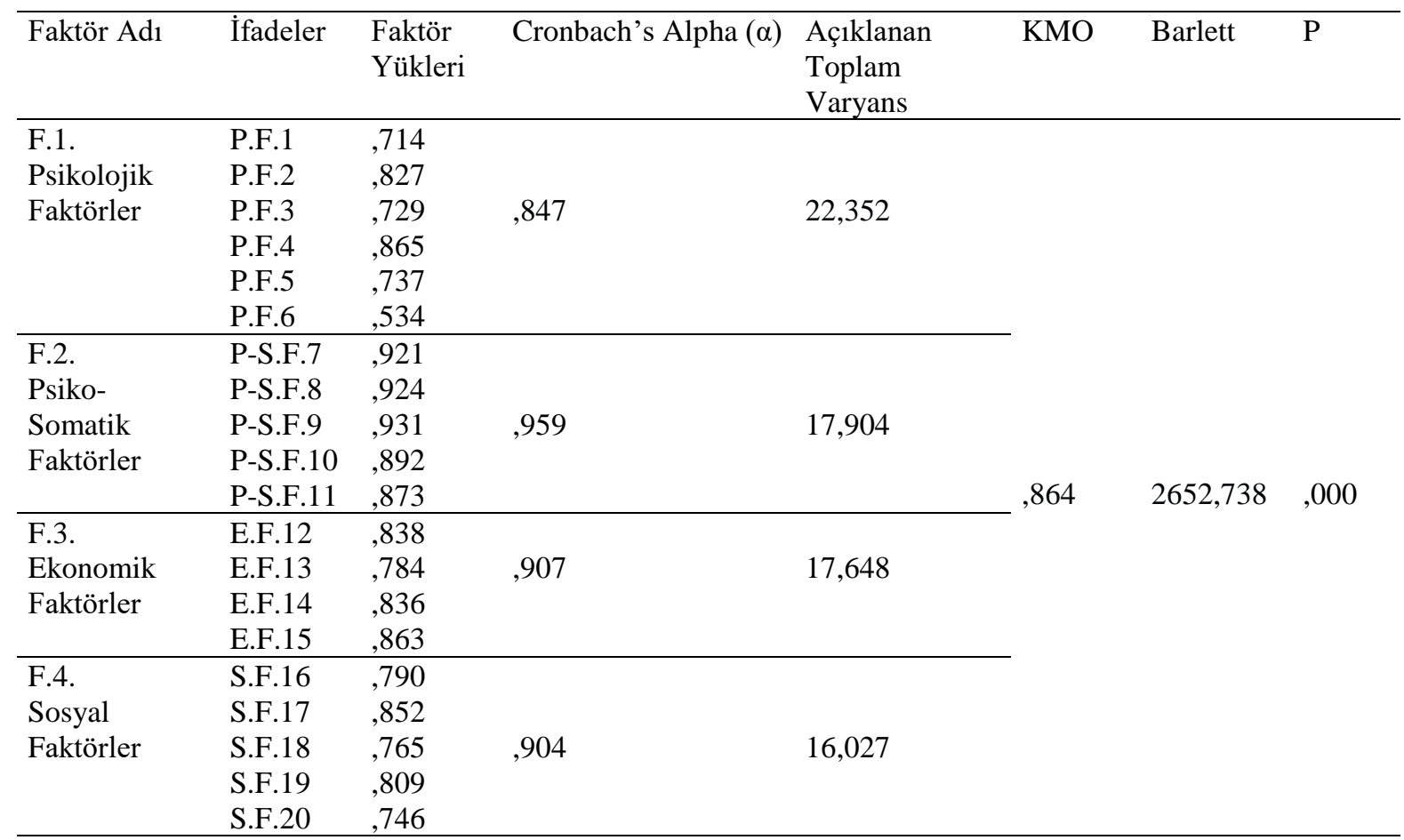

Tablo 3'teki Faktör Analizi Sonuçlarına Göre:

Psikolojik faktör, psiko-somatik faktör, ekonomik faktör ve sosyal faktör boyutlarının Kaiser-Meyer-Olkin (KMO) değeri (,864) olarak bulunmuştur. Barlett Küresellik Testi $=\mathrm{p}<0,000$ (Chisquare=2652,738) olarak tespit edilmiştir. Araştırma ölçeklerinin analizi için varimax rotasyonlu temel bileşenler yönteminden faydalanılmıştır. Araştırmada, Covid-19 Korkusu Ölçeği'nin faktör analizi açısından uygun olduğu görülmüştür.

Tablo 4. Faktör Analizi ve Sonuçları

\begin{tabular}{|c|c|c|c|c|c|c|c|}
\hline Faktör Ad1 & İfadeler & $\begin{array}{l}\text { Faktör } \\
\text { Yükleri }\end{array}$ & Cronbach's Alpha $(\alpha)$ & $\begin{array}{l}\text { Açıklanan } \\
\text { Toplam } \\
\text { Varyans }\end{array}$ & KMO & Barlett & $\mathrm{P}$ \\
\hline F.1. & Y.D.1 & ,801 & & & \multirow{6}{*}{,782 } & \multirow{6}{*}{420,388} & \multirow{6}{*}{, 000} \\
\hline Yüzeysel & Y.D.2 & ,606 & ,701 & 39,121 & & & \\
\hline Davranış & Y.D.3 & 873 & & & & & \\
\hline F.2. & D.D.4 & ,787 & & & & & \\
\hline Derinlemesine & D.D.5 & 892 & ,867 & 32,615 & & & \\
\hline Davranış & D.D.6 & ,892 & & & & & \\
\hline
\end{tabular}

Tablo 4'teki Faktör Analizi Sonuçlarına Göre:

Yüzeysel davranış ve derinlemesine davranış boyutlarının Kaiser-Meyer-Olkin (KMO) değeri (,782) olarak bulunmuştur. Barlett Küresellik Testi=p<0,000 (Chisquare=420,388) olarak saptanmıştır. Araştırma ölçeklerinin analizi için varimax rotasyonlu temel bileşenler yönteminden yararlanılmıştır. Çalışmada, Duygusal Emek Ölçeği’nin faktör analizi açısından uygun olduğu belirlenmiştir. 


\subsection{Demografik Bulgular}

Araştırmada AVM çalışanlarının demografik özelliklerine ilişkin sorular frekans analizi yapılarak test edilmiş ve sonuçları Tablo 5'te sunulmuştur.

Tablo 5. Frekans Analizi ve Sonuçları

\begin{tabular}{|c|c|c|c|}
\hline Demografik Özellikler & Kategoriler & $\mathrm{N}$ & $\%$ \\
\hline \multirow[b]{2}{*}{ Cinsiyet } & Bay & 74 & 43,8 \\
\hline & Bayan & 95 & 56,2 \\
\hline \multirow[b]{2}{*}{ Medeni Durum } & Evli & 88 & 52,1 \\
\hline & Bekâr & 81 & 47,9 \\
\hline \multirow[b]{6}{*}{ Yaş Aralığ1 } & 25 ve Alt1 & 39 & 23,1 \\
\hline & $26-30$ & 46 & 27,2 \\
\hline & $31-35$ & 26 & 15,4 \\
\hline & $36-40$ & 27 & 16,0 \\
\hline & $41-45$ & 14 & 8,3 \\
\hline & 46 ve Üzeri & 17 & 10,1 \\
\hline \multirow[b]{5}{*}{ Eğitim Durumu } & Lise & 73 & 43,2 \\
\hline & Ön lisans & 35 & 20,7 \\
\hline & Lisans & 30 & 17,8 \\
\hline & Yüksek Lisans & 7 & 4,1 \\
\hline & Diğer & 24 & 14,2 \\
\hline \multirow[b]{5}{*}{ Pozisyon } & Personel & 127 & 75,1 \\
\hline & Bölüm Yöneticisi & 9 & 5,3 \\
\hline & MüdürYardımc1sı & 4 & 2,4 \\
\hline & Müdür & 14 & 8,3 \\
\hline & Diğer & 15 & 8,9 \\
\hline \multirow[b]{5}{*}{ Çalışma Süresi } & 1 Yildan Az & 25 & 14,8 \\
\hline & $1-5 \mathrm{Y} 1 \mathrm{l}$ & 82 & 48,5 \\
\hline & 6-10 Y1l & 35 & 20,7 \\
\hline & $11-15$ Y1l & 17 & 10,1 \\
\hline & 16 Yil ve Üzeri & 10 & 5,9 \\
\hline \multirow[b]{4}{*}{ Aylık Gelir (TL) } & $2000-2500$ & 64 & 37,9 \\
\hline & $2501-3000$ & 43 & 25,4 \\
\hline & $3001-3500$ & 34 & 20,1 \\
\hline & 3501 ve Üzeri & 28 & 16,6 \\
\hline
\end{tabular}

Tablo 5'teki Frekans Analizi Sonuçlarına Göre:

Çalışmaya katılanların cinsiyete göre dağılımları incelendiğinde $74 \quad(\% 43,8)$ AVM çalışanının bay olduğu belirlenirken, 95 (\%56,2) AVM çalışanın bayan olduğu saptanmıştır.

Katılımcıların medeni durum açısından dağılımları incelendiğinde 88 (\%52,1) AVM çalışanının evli olduğu, geriye kalan $81(\% 47,9)$ AVM çalışanının bekâr olduğu tespit edilmiştir. $\mathrm{Bu}$ durum katılımcıların çoğunluğunun evlilerden meydana geldiğini göstermektedir.

Araştırmada 25 ve altı yaş aralığıyla 39 (\%23,1), 26-30 yaş aralığıyla 46 (\%27,2), 31-35 yaş aralığıyla $26(\% 15,4), 36-40$ yaş aralığıyla $27(\% 16,0), 41-45$ yaş aralığıyla $14(\% 8,3), 46$ ve üzeri yaş aralığıyla $17(\% 10,1)$ katılımcının belirli yaş aralıklarına göre dağılım gösterdiği belirlenmiştir. 
Çalışmada eğitim düzeyi lise mezunu olan $73(\% 43,2)$ katılımcı örneklemin en kalabalık grubunu oluşturmuştur.

Araştırmada pozisyona göre dağılım incelendiğinde $4(\% 2,4)$ katılımcının müdür yardımcısı, 9 (\%5,3) katılımcının bölüm yöneticisi, 14 (\%8,3) katılımcının müdür, $15(\% 8,9)$ katılımcının diğer ve $127(\% 75,1)$ katılımcının personel olduğu saptanmıştır.

Katılımcıların çalışma süresi incelendiğinde 16 yıl ve üzeri çalışma süresiyle $10(\% 5,9)$ AVM çalışanı örneklemin en küçük grubunu meydana getirmiştir.

Araştırmada AVM çalışanlarının aylık gelir dağılımı incelendiğinde 2000-2500 (TL) aylık gelirle $64(\% 37,9)$ katılımcının en düşük gelir düzeyine sahip olanları meydana getirdiği görülmüştür.

\subsection{Araştırmanın Temel Bulguları}

Araştırmanın temel bulguları çerçevesinde korelasyon ve regresyon analizi yapılmıştır. $\mathrm{Bu}$ analizlerin sonuçları detaylı olarak yorumlanmıştır.

\subsubsection{Korelasyon Analizi ve Sonuçları}

Çalışmada covid-19 korkusunun duygusal emek, çalışan performansı, iş tatmini ve yaşam doyumuyla arasındaki ilişki korelasyon analiziyle test edilmiştir. "İki değişken arasındaki doğrusal ilişki ya da bir değişkenin iki ya da daha fazla değiş̧kenle ilişkisini belirlemek, varsa bu ilişkinin derecesini ölçmek için kullanılan istatistiksel bir yöntem" korelasyon analizi şeklinde ifade edilmektedir. Bu analizin yapılmasındaki esas amaç, bağımsız değişken değiştiğinde bağımlı değişkenin ne yönde değiştiğini tespit etmektir (Sungur, 2018: 115). Bu araştırmanın korelasyon analizi ve sonuçları Tablo 6'da gösterilmiştir.

Tablo 6. Korelasyon Analizi ve Sonuçları

\begin{tabular}{|c|c|c|c|c|c|c|c|c|c|c|c|}
\hline Değişkenler & Ort. & S.S. & $(1)$ & $(2)$ & (3) & $(4)$ & $(5)$ & $(6)$ & $(7)$ & $(8)$ & (9) \\
\hline Psikolojik & 3,7613 & ,94521 & 1 & & & & & & & & \\
\hline Faktörler(1) & & & 169 & & & & & & & & \\
\hline Psiko- & 2,1787 & 1,2389 &, $256^{* *}$ & 1 & & & & & & & \\
\hline \multirow[t]{2}{*}{ Somatik Faktörler(2) } & & &, 001 & & & & & & & & \\
\hline & & & 169 & 169 & & & & & & & \\
\hline Ekonomik & 2,7130 & 1,22585 &, $196^{*}$ &, $307^{* *}$ & 1 & & & & & & \\
\hline \multirow[t]{2}{*}{ Faktörler(3) } & & &, 011 &, 000 & & & & & & & \\
\hline & & & 169 & 169 & 169 & & & & & & \\
\hline Sosyal & 3,5456 & 1,10491 &, $389^{* *}$ & $226^{* *}$ &, $563^{* *}$ & 1 & & & & & \\
\hline \multirow[t]{2}{*}{ Faktörler(4) } & & &, 000 & ,003 &, 000 & & & & & & \\
\hline & & & 169 & 169 & 169 & 169 & & & & & \\
\hline Çalışan & 2,4274 & 1,23995 &,- 084 &, $506^{* *}$ &, 121 & ,044 & 1 & & & & \\
\hline \multirow[t]{2}{*}{ Performansi(5) } & & &, 275 &, 000 &, 118 &, 572 & & & & & \\
\hline & & & 169 & 169 & 169 & 169 & 169 & & & & \\
\hline İş̧ & 3,6317 & 1,15504 & 019 & ,068 &,- 037 & 015 & $264^{* *}$ & 1 & & & \\
\hline \multirow[t]{2}{*}{ Tatmini(6) } & & &, 811 & ,383 &, 630 & ,849 &, 001 & & & & \\
\hline & & & 169 & 169 & 169 & 169 & 169 & 169 & & & \\
\hline
\end{tabular}




\begin{tabular}{|c|c|c|c|c|c|c|c|c|c|c|c|}
\hline Yüzeysel & 3,4497 & 1,11341 &, 027 &, $223^{* *}$ &, 114 &,- 064 & $263^{* *}$ &,- 124 & 1 & & \\
\hline \multirow[t]{2}{*}{ Davranış(7) } & & & ,732 & ,004 &, 141 &, 412 & ,001 & , 108 & & & \\
\hline & & & 169 & 169 & 169 & 169 & 169 & 169 & 169 & & \\
\hline Derinlemesine & 4,0059 & ,97147 &,- 043 & ,021 &,- 056 &,- 066 &, 000 & , 142 &, $502^{* *}$ & 1 & \\
\hline \multirow[t]{2}{*}{ Davranış(8) } & & &, 578 & ,788 &, 473 & ,392 & ,997 &, 065 &, 000 & & \\
\hline & & & 169 & 169 & 169 & 169 & 169 & 169 & 169 & 169 & \\
\hline Yaşam & 3,3361 & 1,09030 &,- 015 & $320^{* *}$ &,- 042 &,- 051 & $232^{* *}$ & $159^{*}$ & $276^{* *}$ & $384^{* *}$ & 1 \\
\hline \multirow[t]{2}{*}{ Doyumu(9) } & & & 848 &, 000 &, 589 &, 509 & 002 & ,039 &, 000 & ,000 & \\
\hline & & & 169 & 169 & 169 & 169 & 169 & 169 & 169 & 169 & 169 \\
\hline
\end{tabular}

**. Correlation is significant at the 0.01 level (2-tailed).

Tablo 6'daki Korelasyon Analizi Sonuçlarına Göre:

Psikolojik faktörlerin çalışan performansı ( $\mathrm{r}=-, 084 ; \mathrm{p}>, 0.05)$, iş tatmini $(\mathrm{r}=, 019 ; \mathrm{p}>, 0.05)$, yüzeysel davranış $(r=, 027 ; \mathrm{p}>, 0.05)$, derinlemesine davranış $(\mathrm{r}=-, 043 ; \mathrm{p}>, 0.05)$, yaşam doyumu (r=-,015;p>,0.05) ile herhangi bir anlamlı ilişkiye sahip olmadığı belirlenmiştir.

Psiko-somatik faktörlerin çalışan performansı ( $\mathrm{r}=, 506 ; \mathrm{p}<, 0.01)$, yüzeysel davranış $(\mathrm{r}=, 223 ; \mathrm{p}<, 0.01)$, yaşam doyumu $(\mathrm{r}=, 320 ; \mathrm{p}<, 0.01)$ ile pozitif anlamlı bir ilişkiye sahip olduğu saptanmıştır. Ancak psiko-somatik faktörlerin iş tatmini $(r=, 068 ; p>, 0.05)$, derinlemesine davranış $(r=, 021 ; p>, 0.05)$ ile herhangi bir anlamlı ilişkiye sahip olmadığg tespit edilmiştir.

Ekonomik faktörlerin çalışan performansı $(\mathrm{r}=, 121 ; \mathrm{p}>, 0.05)$, iş tatmini $(\mathrm{r}=-, 037 ; \mathrm{p}>, 0.05)$, yüzeysel davranış $(\mathrm{r}=, 114 ; \mathrm{p}>, 0.05)$, derinlemesine davranış $(\mathrm{r}=-, 056 ; \mathrm{p}>, 0.05)$, yaşam doyumu ( $\mathrm{r}=-, 042 ; \mathrm{p}>, 0.05)$ ile herhangi bir anlamlı ilişkiye sahip olmadığı görülmüştür.

Sosyal faktörlerin çalışan performansı $(\mathrm{r}=, 044 ; \mathrm{p}>, 0.05)$, iş tatmini $(\mathrm{r}=-, 015 ; \mathrm{p}>, 0.05)$, yüzeysel davranış ( $r=-, 064 ; p>, 0.05)$, derinlemesine davranış ( $(r=-, 066 ; p>, 0.05)$, yaşam doyumu $(\mathrm{r}=-, 051 ; \mathrm{p}>, 0.05)$ ile herhangi bir anlamlı ilişkiye sahip olmadığı belirlenmiştir.

\subsection{2. Çoklu Regresyon Analizi ve Sonuçları}

Çalışmada covid-19 korkusunun duygusal emek, çalışan performansı, iş tatmini ve yaşam doyumu üzerine etkisini test etmek için çoklu regresyon analizi yapılmıştır. Çoklu regresyon analizi, basit regresyon analizinin genişletilmiş şekli olarak ta düşünülebilir (Alpar, 2001: 132). $\mathrm{Bu}$ araştırmanın çoklu regresyon analizi ve sonuçlarına aşağıdaki tablolarda yer verilmiştir.

Araştırmada H1. (Psikolojik faktörler yüzeysel davranışı negatif yönde etkiler), H2. (PsikoSomatik faktörler yüzeysel davranışı negatif yönde etkiler ), H3. (Ekonomik faktörler yüzeysel davranışı negatif yönde etkiler) ve H4. (Sosyal faktörler yüzeysel davranışı negatif yönde etkiler) hipotezlerini test etmek için çoklu regresyon analizi yapılmış ve sonuçları Tablo 7'de sunulmuştur. 
Tablo 7. Psikolojik Faktörler, Psiko-Somatik Faktörler, Ekonomik Faktörler ve Sosyal Faktörlerin Yüzeysel Davranışı Etkilemesine İlişkin Çoklu Regresyon Analizi Sonuçları

Bağımlı Değişken: Yüzeysel Davranış

\begin{tabular}{ll} 
Standartlaşmamış & Standartlaşmış \\
Katsayılar & Katsayılar \\
\hline
\end{tabular}

\begin{tabular}{|c|c|c|c|c|c|c|c|c|}
\hline Değişkenler & $\mathrm{B}$ & S.H. & Beta & t. & p. & $\mathrm{F}$ & $\mathrm{R}^{2}$ & $\Delta \mathrm{R}^{2}$ \\
\hline Sabit & 3,288 & ,378 & & 8,696 &, 000 & 3,594 & ,081 & ,058 \\
\hline Psikolojik Faktörler & ,026 & ,098 & ,022 & ,266 & ,790 & & & \\
\hline Psiko-Somatik Faktörler &, 194 & 072 & ,215 & 2,676 & ,008 & & & \\
\hline Ekonomik Faktörler & ,148 & 085 & ,163 & 1,749 &, 082 & & & \\
\hline Sosyal Faktörler &,- 214 & ,097 &,- 213 & $-2,204$ & 029 & & & \\
\hline
\end{tabular}

Tablo 7'deki Çoklu Regresyon Analizi Sonucuna Göre:

Sosyal faktörler $(H 4)$ 'ün $(\beta=-, 213 ; p<0,05)$ yüzeysel davranışı negatif yönde etkilediği görülmüştür. Yüzeysel davranışa ait varyansın $(\% 5,8)$ 'i sosyal faktörler tarafından açıklanmaktadır $\left(\Delta \mathrm{R}^{2}=, 058 ; \mathrm{p}<0,05\right)$. Fakat psiko-somatik faktörler $(H 2)$ 'nin $(\beta=, 215 ; \mathrm{p}<0,05)$ yüzeysel davranışı pozitif yönde etkilediği belirlenmiştir. Psikolojik faktörler (H1) $(\beta=, 022 ; p>0,05)$ ve ekonomik faktörler (H3)'ün $(\beta=, 163 ; p>0,05)$ yüzeysel davranış1 etkilemediği saptanmıştır. Elde edilen bu bulgulara göre (H4) desteklenmiş olup (H1), (H2) ve (H3) reddedilmiştir.

Çalışmada H5. (Psikolojik faktörler derinlemesine davranışı negatif yönde etkiler), H6. (Psiko-Somatik faktörler derinlemesine davranışı negatif yönde etkiler), H7. (Ekonomik faktörler derinlemesine davranışı negatif yönde etkiler) ve H8. (Sosyal faktörler derinlemesine davranışı negatif yönde etkiler) hipotezlerini test etmek için çoklu regresyon analizi yapılmış ve sonuçları Tablo 8'de gösterilmiştir.

Tablo 8. Psikolojik Faktörler, Psiko-Somatik Faktörler, Ekonomik Faktörler ve Sosyal Faktörlerin Derinlemesine Davranışı Etkilemesine İlişkin Çoklu Regresyon Analizi Sonuçları Bağımlı Değişken: Derinlemesine Davranış

\begin{tabular}{|c|c|c|c|c|c|c|c|c|}
\hline \multirow[b]{2}{*}{ Değişkenler } & \multicolumn{2}{|c|}{$\begin{array}{l}\text { Standartlaşmamış } \\
\text { Katsayılar } \\
\end{array}$} & \multirow{2}{*}{$\begin{array}{l}\text { Standartlaşmış } \\
\text { Katsayılar } \\
\text { Beta }\end{array}$} & \multirow[b]{2}{*}{ t. } & \multirow[b]{2}{*}{ p. } & \multirow[b]{2}{*}{$\mathrm{F}$} & \multirow[b]{2}{*}{$\mathrm{R}^{2}$} & \multirow[b]{2}{*}{$\Delta \mathrm{R}^{2}$} \\
\hline & $\mathrm{B}$ & S.H. & & & & & & \\
\hline Sabit & 4,261 & ,343 & & 12,432 & 000 & 311 & ,008 &,- 017 \\
\hline Psikolojik Faktörler &,- 033 & ,089 &,- 032 &,- 368 & ,713 & & & \\
\hline Psiko-Somatik Faktörler & r , 040 & ,066 & ,051 & ,613 &, 541 & & & \\
\hline Ekonomik Faktörler &,- 033 &, 077 &,- 041 &,- 427 & 670 & & & \\
\hline Sosyal Faktörler &,- 037 & ,088 &,- 042 &,- 421 & 674 & & & \\
\hline
\end{tabular}

Tablo 8'deki Çoklu Regresyon Analizi Sonucuna Göre:

Psikolojik faktörler (H5) ( $\beta=-, 032 ; p>0,05)$, psiko-somatik faktörler (H6) $(\beta=, 051 ; p>0,05)$, ekonomik faktörler (H7) $(\beta=-, 041 ; p>0,05)$ ve sosyal faktörler (H9)'un $(\beta=-, 042 ; p>0,05)$ 
derinlemesine davranışı etkilemediği tespit edilmiştir. Elde edilen bu bulgulara göre (H5), (H6) (H7) ve (H8) reddedilmiştir.

Araştırmada H9. (Psikolojik faktörler çalışan performansını negatif yönde etkiler), H10. (Psiko-Somatik faktörler çalışan performansını negatif yönde etkiler), H11. (Ekonomik faktörler çalışan performansını negatif yönde etkiler) ve H12. (Sosyal faktörler çalışan performansını negatif yönde etkiler) hipotezlerini test etmek için çoklu regresyon analizi yapılmış ve sonuçlarına Tablo 9'da yer verilmiştir.

Tablo 9. Psikolojik Faktörler, Psiko-Somatik Faktörler, Ekonomik Faktörler ve Sosyal Faktörlerin Çalışan Performansını Etkilemesine İlişkin Çoklu Regresyon Analizi Sonuçları

Bağımlı Değişken: Çalışan Performansı

Standartlaşmamış Standartlaşmış

Katsayılar Katsayılar

\begin{tabular}{|c|c|c|c|c|c|c|c|c|}
\hline Değişkenler & B & S.H. & Beta & t. & p. & $\mathrm{F}$ & $\mathrm{R}^{2}$ & $\Delta \mathrm{R}^{2}$ \\
\hline Sabit & 2,321 & ,366 & & 6,339 & 000 & 17,967 &, 305 & 288 \\
\hline Psikolojik Faktörler &,- 304 & ,095 &,- 232 & $-3,217$ & ,002 & & & \\
\hline Psiko-Somatik Faktörler &, 567 & 070 &, 567 & 8,097 & 000 & & & \\
\hline Ekonomik Faktörler &,- 016 &, 082 &,- 016 &,- 201 & ,841 & & & \\
\hline Sosyal Faktörler & ,017 & ,094 & ,015 &, 178 & 859 & & & \\
\hline
\end{tabular}

Tablo 9'daki Çoklu Regresyon Analizi Sonucuna Göre:

Psikolojik faktörler (H9)'un $(\beta=-, 232 ; \mathrm{p}<0,05)$ çalışan performansını negatif yönde etkilediği görülmüştür. Çalışan performansına ait varyansın $(\% 28,8)$ 'i psikolojik faktörler tarafından açıklanmaktadır $\left(\Delta \mathrm{R}^{2}=, 288 ; \mathrm{p}<0,05\right)$. Ancak psiko-somatik faktörler (H10)'un $(\beta=, 567 ; p<0,05)$ çalışan performansını pozitif yönde etkilediği belirlenmiştir. Ekonomik faktörler (H11) $(\beta=-, 016 ; p>0,05)$ ve sosyal faktörler (H12)'nin $(\beta=, 015 ; p>0,05)$ çalışan performansını etkilemediği saptanmıştır. Elde edilen bu bulgulara göre (H9) desteklenmiş olup (H10) (H11) ve (H12) reddedilmiştir.

Çalışmada H13. (Psikolojik faktörler iş tatminini negatif yönde etkiler), H14. (PsikoSomatik faktörler iş tatminini negatif yönde etkiler), H15. (Ekonomik faktörler iş tatminini negatif yönde etkiler) ve H16. (Sosyal faktörler iş tatminini negatif yönde etkiler) hipotezlerini test etmek için çoklu regresyon analizi yapılmış ve sonuçları Tablo 10'da sunulmuştur. 
Tablo 10. Psikolojik Faktörler, Psiko-Somatik Faktörler, Ekonomik Faktörler ve Sosyal Faktörlerin İş Tatminini Etkilemesine İlişkin Çoklu Regresyon Analizi Sonuçları

Bağımlı Değişken: İş Tatmini

\begin{tabular}{ll}
$\begin{array}{ll}\text { Standartlaşmamış } \\
\text { Katsayılar }\end{array}$ & $\begin{array}{l}\text { Standartlaşmış } \\
\text { Katsayılar }\end{array}$ \\
\hline
\end{tabular}

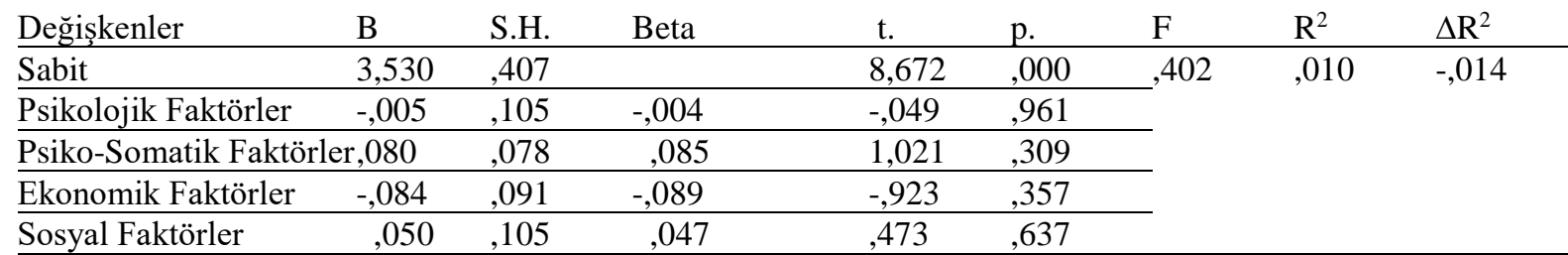

Tablo 10'daki Çoklu Regresyon Analizi Sonucuna Göre:

Psikolojik faktörler (H13) $(\beta=-, 004 ; p>0,05)$, psiko-somatik faktörler (H14) $(\beta=, 085 ; p>0,05)$, ekonomik faktörler (H15) $(\beta=-, 089 ; p>0,05)$ ve sosyal faktörler (H16)'nın $(\beta=, 047 ; p>0,05)$ iş tatminini etkilemediği tespit edilmiştir. Elde edilen bu bulgulara göre (H13), (H14) (H15) ve (H16) reddedilmiştir.

Araştırmada H17. (Psikolojik faktörler yaşam doyumunu negatif yönde etkiler), H18. (Psiko-Somatik faktörler yaşam doyumunu negatif yönde etkiler ), H19. (Ekonomik faktörler yaşam doyumunu negatif yönde etkiler) ve H20. (Sosyal faktörler yaşam doyumunu negatif yönde etkiler) test etmek için çoklu regresyon analizi yapılmış ve sonuçları Tablo 11 'de gösterilmiştir.

Tablo 11. Psikolojik Faktörler, Psiko-Somatik Faktörler, Ekonomik Faktörler ve Sosyal Faktörlerin Yaşam Doyumunu Etkilemesine İlişkin Çoklu Regresyon Analizi Sonuçları Bağımlı Değişken: Yaşam Doyumu

\begin{tabular}{ll} 
Standartlaşmamış & Standartlaşmış \\
Katsayılar & Katsayılar \\
\hline
\end{tabular}

\begin{tabular}{|c|c|c|c|c|c|c|c|c|}
\hline Değişkenler & $\mathrm{B}$ & S.H. & Beta & t. & p. & $\mathrm{F}$ & $\mathrm{R}^{2}$ & $\Delta \mathrm{R}^{2}$ \\
\hline Sabit & 3,355 & ,360 & & 9,323 &, 000 & 6,221 & ,132 & ,111 \\
\hline Psikolojik Faktörler &,- 085 &, 093 &,- 074 &,- 916 & ,361 & & & \\
\hline Psiko-Somatik Faktörle &, 340 & 069 &, 386 & 4,933 &, 000 & & & \\
\hline Ekonomik Faktörler &,- 109 & ,081 &,- 123 & $-1,358$ &, 176 & & & \\
\hline Sosyal Faktörler &,- 040 & ,093 &,- 040 &,- 432 & 667 & & & \\
\hline
\end{tabular}

Tablo 11'deki Çoklu Regresyon Analizi Sonucuna Göre:

Psiko-Somatik faktörler (H17)'nin $(\beta=, 386 ; p<0,05)$ yaşam doyumunu pozitif yönde etkilediği görülmüştür. Psikolojik faktörler (H18) ( $\beta=-, 074 ; p>0,05)$, ekonomik faktörler (H19) $(\beta=-, 123 ; p>0,05)$ ve sosyal faktörler (H20)'nin $(\beta=-, 040 ; p>0,05)$ yaşam doyumunu etkilemediği belirlenmiştir. Elde edilen bu bulgulara göre (H17), (H18), (H19) ve (H20) reddedilmiştir. 


\section{Sonuç ve Tartışma}

Covid-19'un yarattığı kriz, insanın olduğu her alanda durağanlaşma ile hareketsizliği kaçınılmaz hale getirmiştir (Yıldırımvuran vd., 2020: 49). Nitekim yaşamın her bir alanında problemler ortaya çıkarken; yaşam biçimlerinin yeni normallerle şekillendiği, eğitimden sağlığa her bir alanda covid-19'a yönelik düzenlemelerin gerçekleştirildiği de görülmektedir (Paksoy, 2020: 135). Bu pandemi sürecinde iyi hazırlanmış bilgilendirme tasarımına sahip web sitelerinin, internette ya da sosyal çevrede yer alan kompleks verilerden gerekli olanları ve gerçek olanları ön plana çıkarıp, hayatı kolaylaştırdığı görülmektedir (Gürsu, 2020). Diğer yandan toplumun bütünü pandemi sonrası için de hazırlanmalıdır. Bu süreç içerisinde en önem arz eden hususta farkındalıktır. Dolayısıyla toplumda genel farkındalığın yükseltilmesi adına yazılı ve görsel medya aracılığıyla güvenilir ve doğru bilgilendirmelerin yapılması, eğitimlerin yürütülmesi, yetkililerin pandemiyle ilgili bilgileri şeffaflıkla paylaşmayı sürdürmesi mücadele etmedeki önemli unsurlar arasında yer almaktadır. Küresel çaptaki bir pandemiyle mücadele ancak birlik ve beraberlik sağlandığ taktirde kazanılabilir (Gencer, 2020: 1167).

Bu araştırmada covid-19 korkusu, duygusal emek, çalışan performansı, iş tatmini ve yaşam doyumu konuları ele alınmıştır. Araştırmada covid-19 korkusunun duygusal emek, çalışan performansı, iş tatmini ve yaşam doyumu üzerine etkisi test edilmiştir. Literatür incelemesi sonucunda bu konuların birlikte ele alındığı herhangi bir çalışmanın bulunmadığı görülmüştür. Böyle bir araştırmanın AVM çalışanları üzerinde gerçekleştirilmediği de belirlenmiştir. Bütün bunların yapılan araştırmayı "ilk" ve "farklı" kılması açısından önem arz ettiği düşünülmüştür. Araştırma verileri frekans, güvenirlik, faktör ve korelasyon analiziyle test edilmiştir. Araştırma ana hipotezlerini test etmek için de çoklu regresyon analizinden faydalanılmıştır. $\mathrm{Bu}$ araştırmanın sonuçlarını genel olarak değerlendirmek gerekirse:

Araştırmanın çoklu regresyon analizi sonucunda psiko-somatik, psikolojik, ekonomik faktörlerin yüzeysel davranışı; psikolojik, psiko-somatik, ekonomik, sosyal faktörlerin derinlemesine davranışı; psiko-somatik, ekonomik, sosyal faktörlerin çalışan performansını; psikolojik, psiko-somatik, ekonomik, sosyal faktörlerin iş tatminini; psikolojik, psiko-somatik, ekonomik, sosyal faktörlerin yaşam doyumunu etkilemediği görülmüştür. Araştırmadan beklenen sonuç covid-19 korkusu boyutlarının duygusal emek, çalışan performansı, iş tatmini ve yaşam doyumunu etkileyeceği yönündeydi. Fakat bu beklenen sonuçların araştırmada teyit edilemediği görülmüştür. Araştırmadaki (H1), (H2), (H3), (H5), (H6), (H7), (H8), (H10), (H11), (H12), (H13), (H14), (H15), (H16), (H17), (H18), (H19) ve (H20) reddedilmiştir.

Araştırmanın çoklu regresyon analizi sonucunda sosyal faktörlerin yüzeysel davranışı negatif yönde etkilediği görülmüştür. Araştırmadan elde edilen sonuca göre (H4) kabul 
edilmiştir. $\mathrm{Bu}$ sonuç sosyal faktörlerin yüzeysel davranış açısından önemini ortaya koymaktadır. Sosyal faktörlerin varlığı insanların yüzeysel davranış sergilemelerinde etkili olmaktadir.

Araştırmanın sonuçlarından biri de psikolojik faktörlerin çalışan performansını negatif yönde etkilediğidir. Araştırmadan elde edilen bu sonuca göre (H9) kabul edilmiştir. Nitekim çalışanın yaşadığı psikolojik durumlar performansına yansıyabilir.

Araştırma çerçevesinde ileride yapılacak çalışmalar konusunda bazı öneriler verilebilir. Örneğin covid-19 korkusuyla ilgili çalışmalar AVM sayısı artırılarak yapılabilir. Covid-19 korkusuyla ilgili çalışmalar farklı örneklem grupları üzerinde gerçekleştirilebilir. Gelecekteki çalışmalarda farklı analiz yöntemleri, farklı ve yeni değişkenler kullanılabilir. Covid-19 korkusuyla ilgili gelecekte yapılacak çalışmalarda farklı modeller ortaya konulup test edilebilir. 


\section{KAYNAKÇA}

Akşit Aşık, N. (2010). Çalışanların iş doyumunu etkileyen bireysel ve örgütsel faktörler ile sonuçlarına ilişkin kavramsal bir değerlendirme, Türk Idare Dergisi, 467, 31-51.

Alpar, R. (2001). Spor bilimlerinde uygulamalı istatistik, 2. Baskı, Nobel Yayın Dağıtım, Ankara, 220.

Arpacı, I., Karataş, K. ve Baloğlu, M. (2020). The development and initial tests for the psychometric properties of the covid-19 phobia scale (C19P-S), Personality and Individual Differences, 164, 1-6.

Aşan, Ö. ve Özyer, K. (2008). Duygusal bağlılık ile iş tatmini ve iş tatmininin alt boyutları arasındaki ilişkileri analiz etmeye yönelik ampirik bir çalışma, Süleyman Demirel Üniversitesi İktisadi ve İdari Bilimler Fakültesi Dergisi, 13(3), 129-151.

Aydın, A., Üçüncü, K. ve Taşdemir, T. (2010). İşletmelerde uygulanan toplam kalite yönetimi çalışmalarının çalışan performansı üzerine etkileri, International Journal of Economic and Administrative Studies, 5, 42-62.

Aydın, B. ve Doğan, M. (2020). Yeni koronavirüs (covid-19) pandemisinin turistik tüketici davranışları ve Türkiye turizmi üzerindeki etkilerinin değerlendirilmesi, Pazarlama Teorisi ve Uygulamaları Dergisi, 6(1), 93115.

Aykaç, M. ve Murat, G. (2020). Covid-19 ve emek piyasaları: etkiler ve muhtemel yönelişler, Trakya Üniversitesi Iktisadi ve İdari Bilimler Fakültesi E-Dergi, 8(2), 91-122.

Baltacı, F., Kavacık, M., Şentürk, F.K. ve Kurar, İ. (2014). Yöneticilerin liderlik özelliklerinin çalışanların iş tatmini üzerindeki etkisi: Alanya'da bulunan 4 ve 5 yıldızlı otel çalışanları üzerine bir araştırma, $A \dot{I} B \ddot{U}$ Sosyal Bilimler Enstitüsü Dergisi, 14(2), 59-85.

Barut, A. ve Yerdelen Kaygın, C. (2020). Covid-19 pandemisinin seçilmiş borsa endeksleri üzerine etkisinin incelenmesi, Gaziantep University Journal of Social Sciences, Special Issue, 59-70.

Bilgin, T. (2019). Duygu durumlarının iş tatmini ve iş performansı ile olan ilişkisini belirlemeye yönelik bir araştırma, Yüksek Lisans Tezi, Uludağ Üniversitesi, Sosyal Bilimler Enstitüsü.

Binbaşığlu, H. (2020). Yeni tip koronavirüs (covid-19) döneminde ulusal turizm örgütlerinin resmi web sitelerinin bir iletişim aracı olarak incelenmesi, Turizm Akademik Dergisi, 7(2), 73-88.

Bozkurt, Y., Zeybek, Z. ve Aşkın, R. (2020). Covid-19 pandemisi: psikolojik etkileri ve terapötik müdahaleler, Istanbul Ticaret Üniversitesi Sosyal Bilimler Dergisi, 19(37), 304-318.

Brayfield, A. ve Rothe, H. (1951). An index of job satisfaction, Journal of Applied Psychology, 35(5), $307-311$.

Brotheridge, C. ve Grandey, A. (2002). Emotional labor and burnout: comparing two perspectives of "people work", Journal of Vocational Behavior, 60(1), 17-39.

Brotheridge, C. ve Lee, R. (2002). Testing a conservation of resources model of the dynamics of emotional labor, Journal of Occupational Health Psychology, 7(1), 57-67.

Bulut, R. ve Pınar, C. (2020). Covid-19 pandemisi döneminde Türkiye’de istihdam ve işsizlik, Oğuzhan Sosyal Bilimler Dergisi, 2(2), 217-225.

Büyükyılmaz, O., Karakulle, İ. ve Karataş, İ. (2019). Örgütsel kariyer yönetiminin duygusal bağlılık üzerindeki etkisinde iş tatmininin aracılık rolü, Çankırı Karatekin Üniversitesi İktisadi ve İdari Bilimler Fakültesi Dergisi, 8(1), 1-29.

Chu, K. ve Murrmann, S. (2006). Development and validation of the hospitality emotional labor scale, Tourism Management, 27(6), 1181-1191.

Cinel, E.A. (2020). Covid-19'un küresel makroekonomik etkileri ve beklentiler, Politik Ekonomik Kuram, 4(1), 124-140.

Çaykuş, E.F. ve Mutlu Çaykuş, T. (2020). Covid-19 pandemi sürecinde çocukların psikolojik dayanıklılığını güçlendirme yolları: ailelere, öğretmenlere ve ruh sağlığı uzmanlarına öneriler, Avrasya Sosyal ve Ekonomi Araştırmaları Dergisi (ASEAD), 7(5), 95-113.

Çetin, C. ve Anuk, Ö. (2020). Covid-19 pandemi sürecinde yalnızlık ve psikolojik dayanıklılık: bir kamu üniversitesi öğrencileri örneklemi, Avrasya Sosyal ve Ekonomi Araştırmaları Dergisi (ASEAD), 7(5), 170-189.

Çoruk, A. (2014). Yükseköğretim kurumlarında görev yapan idari personelin duygusal emek davranışları, Ondokuz Mayıs Üniversitesi Ĕ̈itim Fakültesi Dergisi, 33(1), 79-94.

Çöl, G. (2008). Algılanan güçlendirmenin isgören performansı üzerine etkileri, Doğuş Üniversitesi Dergisi, 9(1), 35-46.

Demir, N. (2007). Örgüt Kültürü ve İş Tatmini, Türkmen Kitapevi, 1. Baskı, İstanbul, 301.

Diefendorff, J.M., Croyle, M.H. ve Gosserand, R.H. (2005). The dimensionality and antecedents of emotional labor strategies, Journal of Vocational Behavior, 66(2), 339-357.

Diener, E. Lucas, R.E., Oishi, S. ve Suh, E.M. (2002). Looking up and looking down: weighting good and bad information in life satisfaction judgments, Personality and Social Psychology Bulletin, 28(4), 437-445.

Diener, E. ve Lucas, R.E. (1999). Personality and Subjective Well-Being. In D. Kahneman, E. Diener, \& N. Schwarz (Eds.), Well-Being: The Foundations of Hedonic Psychology (P.3). New York, Ny: Russell Sage Foundation. 
Diener, E. ve Martin E.S. (2004). Beyond money: toward an economy of well-being, Pyschological Science in the Public Interest, 5(1), 1-31.

Diener, E. ve Suh, E. (1997). Measuring quality of life: economic, social and subjective indicators, Social Indicators Research, 40(1), 189-216.

Diener, E., Emmons, R.A., Larsen, R.J. ve Griffin, S. (1985). The satisfaction with life scale, Journal of Personality Assessment, 49(1), 71-75.

Diktaş, G. ve Özgeldi, M. (2020). Çalışan performansı ve işten ayrılma niyeti konularında örgütsel sinizm ve sosyal zekânın rolü, Yönetim ve Ekonomi Araştırmaları Dergisi, 18(2), 11-28.

Doğan, B.G., Laçin, E. ve Tutal, N. (2015). Predicatives of the workers burnout level: life satisfaction and social support, Procedia-Social and Behavioral Sciences, 191, 1801-1806.

Doğan, S. ve Kır, A. (2018). Örgütsel sessizlik, tükenmişlik sendromu ve çalışan performansı ilişkisi, Ömer Halisdemir Üniversitesi İktisadi ve İdari Bilimler Fakültesi Dergisi, 11(4), 1-14.

Dormann, C. ve Zapf, D. (2001). Job satisfaction: a meta-analysis of stabilities, Journal of Organizational Behavior, 22(5), 483-504.

Dost, M.T. (2007). Üniversite öğrencilerinin yaşam doyumunun bazı değişkenlere göre incelenmesi, Pamukkale Üniversitesi Ĕ̈itim Fakültesi Dergisi, 2(22), 132- 143.

Duman, N. (2017). Duygusal emek: bir literatür değerlendirmesi, International Journal Entrepreneurship and Management Inquiries Dergisi, 1(1), 29-39.

Duman, N. (2020). Üniversite öğrencilerinde covid-19 korkusu ve belirsizliğe tahammülsüzlük, The Journal of Social Science, 4(8), 426-437.

Duygun, A. (2020). Covid-19 pandemisi sırasında tüketicilerin yaşam tarzlarının değerlendirilmesi, International Academic Journal (Econder), 4(1), 232-247.

Ek, S., İlhanlı, H. ve Kahraman Özözen, S. (2020). Covid-19'un zayıf halkası: yaşlı nüfus, Türk Coğrafya Dergisi 76, 33-44.

Elbay Yeni, R., Kurtulmuş, A., Arpacıoğlu, S. ve Karadere, E. (2020). Depression, anxiety, stress levels of physicians and associated factors in covid-19 pandemics, Psychiatry Research, 290, 1-5.

Ercan, İ. ve Kan, İ. (2004). Ölçeklerde güvenirlik ve geçerlik, Uludă̆ Üniversitesi Tıp Fakültesi Dergisi, 30(3), 211-216.

Erdal, N. (2020). Sağlık kurumlarında ilişki yöneliminin çalışan performansı üzerine etkisi, Avrasya Sosyal ve Ekonomi Araştırmaları Dergisi (ASEAD), 7(6), 310-327.

Gavcar, E. ve Topaloğlu, C. (2008). Kamuya ait konaklama işletmelerinin yöneticilerinde iş doyumu (öğretmenevi müdürleri örneği), Yönetim Bilimleri Dergisi, 6(2), 59-74.

Gencer, N. (2020). Pandemi sürecinde bireylerin koronavirüs (kovid-19) korkusu: Çorum örneği, Usbad Uluslararast Sosyal Bilimler Akademi Dergisi, 1154-1172.

Güler, H. ve Marşap, A. (2019). Günümüz organizasyonlarında duygusal emeğin tükenmişlik ve işten ayrılma niyetine etkisi: akademisyenler üzerinde bir araştırma, Erciyes Üniversitesi İktisadi ve İdari Bilimler Fakültesi Dergisi, (0)53, 285-308.

Günay Aktaş, S. (2020). Küresel sağlıktan sağlık turizmine covid-19, Türk Coğrafya Dergisi, 76, 107-114.

Güney, S. (2007). Yönetim ve Organizasyon, Ankara, 2. Bask1, Nobel Yayın, 710.

Güngör, M. (2009). Duygusal emek kavramı: süreci ve sonuçları, Kamu-İş Dergisi, 11(1), 167-184.

Güngör M. (2017). Duygusal emek \& tinsel emek, 1. Basım, Türkmen Kitabevi, İstanbul, 164.

Güriș S. ve Astar, M. (2014). Bilimsel araştırmalarda SPSS ile istatistik, Der Yayınları, İstanbul, 512.

Gürsu, İ. (2020). Pandemi sürecinde bilgilendirme tasarımı, İnönü Üniversitesi Kültür ve Sanat Dergisi, 6(1), 113.

Hochschild, A.R. (1983). The managed heart. commercialization of human feeling, Berkeley: University of California Press.

Hur, W., Rhee, S. ve Ahn, K. (2016). Positive psychological capital and emotional labor in korea: the job demandsresources approach, The International Journal of Human Resource Management, 27(5), 477-500.

Ilkım Şimşek, D. ve Derin, N. (2018). Algılanan iş güvencesizliği, iş tatmini ve birey-örgüt uyumu kavramları arasındaki ilişkiler, Sosyal Ekonomik Araştırmalar Dergisi, 18(36), 238-254.

İşcan, Ö.F. ve Timuroğlu, M.K. (2007). Örgüt kültürünün iş tatmini üzerindeki etkisi ve bir uygulama, Atatürk Üniversitesi İktisadi ve İdari Bilimler Dergisi, 21(1), 119-135.

Jiang, F., Deng, L., Zhang, L., Cai, Y., Cheung, C.W. ve Xia, Z. (2020). Review of the clinical characteristics of coronavirus disease 2019 (covid-19), Journal of General Internal Medicine, 35(5), 1545-1549.

Jones, A.W. (2001). Caring labor and class consciousness: the class dynamics of gendered work, Sociological Forum, 16(2), 281-299.

Jonsson, P. (2000). An empirical taxonomy of advanced manufacturing technology, International Journal of Operations \& Production Management, 20(12), 1446-1474.

Judge, T.A., Bono, J.E. ve Locke, E.A. (2000). Personality and job satisfaction: the mediating role of job characteristics, Journal of Applied Psydtolagy, 85(2), 237-249. 
Karasar, N. (2005). Bilimsel araştırma yöntemi, 15 Baskı, Nobel Yayın Dağıtım, Ankara, 292.

Kesen, M. (2015). Örgütsel demokrasinin çalışan performansı üzerine etkileri: örgütsel özdeşleşmenin aracılık rolü, Çankırı Karatekin Üniversitesi Sosyal Bilimler Enstitüsü Dergisi, 6(2), 535-562.

Keser A. (2005). İş doyumu ve yaşam doyumu ilişkisi: otomotiv sektöründe bir uygulama, Çalışma ve Toplum, 4, 77-95.

Kılıç, B., Aslan, H. ve Gövce, M. (2020). Covid-19 sonrası turistik tüketim tutumu, Gaziantep University Journal of Social Sciences, Special Issue, 554-570.

Kirci Çevik, N. ve Korkmaz, O. (2014). Türkiye'de yaşam doyumu ve iş doyumu arasındaki ilişkinin iki değişkenli sıralı probit model analizi, Niğde Üniversitesi İktisadi ve Iddari Bilimler Fakültesi Dergisi, 7(1), 126-145.

Kobayashi, T., Jung, S.M., Linton, N.M., Kinoshita, R., Hayashi, K., Miyama, T. ve Nishiura, H. (2020). Communicating the risk of death from novel coronavirus disease (covid-19), Journal of Clinical Medicine 9(2), 1-7.

Kolbaşı, E. ve Bağcı, Z. (2019). İş doyumu ve yaşam doyumu ilişkisi: bir kamu kurumu üzerinde analitik bir araştırma, Anemon Muş Alparslan Üniversitesi Sosyal Bilimler Dergisi, 7(4), 119-123.

Kökden Çivit, F. ve Işık, M. (2018). Çalışma hayatında duygusal emek ve işe yabancılaşma ilişkisi: banka çalışanları üzerine bir uygulama, Süleyman Demirel Üniversitesi İktisadi ve İdari Bilimler Fakültesi Dergisi, 23(4), 1215-1237.

Köroğlu Ö. (2012). İçsel ve dışsal iş doyum düzeyleri ile genel iş doyum düzeyi arasındaki ilişkinin belirlenmesi: turist rehberleri üzerinde bir araştırma, Doğuş Üniversitesi Dergisi, 13(2), 275-289.

Kulualp Göktaş, H. ve Sarı, Ö. (2018). Duygusal emek: okul öncesi öğretmenleri üzerine bir içerik analizi, Uluslararası Yönetim İktisat ve İşletme Dergisi, 14(4), 1167-1181.

Ladikli, N., Bahadır, E., Yumuşak, F.N., Akkuzu, H., Karaman, G. ve Türkkan, Z. (2020). Kovid-19 korkusu ölçeği’nin Türkçe güvenirlik ve geçerlik çalışması, Uluslararası Sosyal Bilimler Dergisi, 3(2), 71-80.

Lin, C.Y. (2020). Social reaction toward the 2019 novel coronavirus (covid-19), Social Health and Behavior, 3(1), $1-2$.

Lu, X. ve Guy, M.E. (2014). How emotional labor and ethical leadership affect job engagement for chinese public servants, Public Personnel Management, 43(1), 3-24.

Mavi, Y. (2016). Duygusal emek: etkilediği ve etkilendiği faktörler üzerine bir alan çalışması, Yüksek Lisans Tezi, Kahramanmaraş Sütçü İmam Üniversitesi, Sosyal Bilimler Enstitüsü, Kahramanmaraş.

Niewiadomski, P. (2020). Covid-19: from temporary de-globalisation to a re-discovery of tourism? Tourism Geographies, 22(3), 651-656.

Nunnally, J.C. (1978). Psychometric Theory, New York: McGraw-Hill, 701.

Okutan, M. ve Tengilimoğlu, D. (2002). İş ortamında stres ve stresle başa çıkma yöntemleri: bir alan uygulaması, Gazi Üniversitesi İktisadi ve İdari Bilimler Fakültesi Dergisi, 3, 15-42.

Oshagbemi, T. (2003). Personal correlates of job satisfaction: emprical evidence form UK. Universities, International Journal of Social Economics, 30(12), 1210-1226.

Özdemir, D. ve Arpacıŏlu, S. (2020). Sosyal medya kullanımı, sağlık algısı ve sağlı arama davranışının koronavirüs korkusu üzerine etkisi, Psikiyatride Güncel Yaklaşımlar, 12(Suppl 1), 364-381.

Özdemir, L. (2020). Covid-19 pandemisinin Bist Sektör Endeksleri üzerine asimetrik etkisi, Finans Ekonomi ve Sosyal Araştırmalar Dergisi, 5(3), 546-556.

Özpehlivan, M. (2018). İş tatmini: kavramsal gelişsimi, bireysel ve örgütsel etkileri, yararları ve sonuçları, Kırklareli Üniversitesi Sosyal Bilimler Dergisi, 2(2), 43-70.

Pakpour, A.H. ve Griffiths, M.D. (2020). The fear of covid-19 and its role in preventive behaviors, Journal of Concurrent Disorders, 2(1), 58-63.

Paksoy, H.M. (2020). Covid-19 pandemisi ile oluşan korku ve davranışlara inancın etkisi üzerine bir araştırma: Türkiye örneği, Kahramanmaraş Sütçü İmam Üniversitesi İktisadi ve İdari Bilimler Fakültesi Dergisi, 10(2), 135-155.

Pavot, W.G., Diener, E., Colvin, C.R. ve Sandvik, E. (1991). Further validation of the satisfaction with life scale: evidence fort the cross method convergence of well-being measures, Journal of Personality Assessment, 57(1), 149-161.

Petrescu, A.I. ve Simmons, R. (2008). Human resource management practices and workers job satisfaction, International Journal of Manpower, 29(7), 651-667.

Sekaran, U. (1992). Research methods for business, John Wiley And Sons, Canada.

Sungur, O. (2018). Korelasyon Analizi, Ed.: Şeref Kalaycı, SPSS Uygulamalı Çok Değişkenli İstatistik Teknikleri, 9. Baskı, Dinamik Akademi, Ankara.

Şit, A. ve Telek, C. (2020). Covid-19 pandemisinin altın ons fiyatı ve dolar endeksi üzerine etkileri, Gaziantep University Journal of Social Sciences, Special Issue, 1-13.

Tosunoğlu, Ş. ve Kasal, S. (2020). Yeni koronavirüs (covid-19) salgını ve sağlıklı küresel ekonomi için politika uygulamalar1: IMF'nin rolü, Anadolu Üniversitesi İktisat Fakültesi Dergisi, 2(1), 35-49. 
Tutar, H. ve Altınöz, M. (2010). Örgütsel iklimin işgören performansı üzerine etkisi: Ostim İmalât İşletmeleri çalışanları üzerine bir araştırma, Ankara Üniversitesi SBF Dergisi, 65(2), 195-218.

Tuzgöl Dost, M. (2007). Üniversite öğrencilerinin yaşam doyumunun bazı değişkenlere göre incelenmesi (examining life satisfaction levels of university students in terms of some variables), Pamukkale Üniversitesi Ĕ̈itim Fakültesi Dergisi, 22(22), 132-143.

Tümkaya, S., Hamarta, E., Deniz, M.E., Çelik M. ve Aybek B. (2008). Duygusal zeka mizah tarzı ve yaşam doyumu: üniversite öğretim elemanları üzerine bir araştırma, Türk Psikolojik Danışma ve Rehberlik Dergisi, 3(30), 1-18.

Türkmen, A. (2016). Örgütsel stresin iş gücü performansına etkileri, Route Educational and Social Science Journal Volume, 3(4), 1-27.

Ural, A. ve Kılıç, İ. (2006). Bilimsel araştırma süreci ve SPSS ile veri analizi, 2. Basım, Detay Yayıncılık, Ankara, 302.

Ülbeği, İ.K., İplik, E. ve Yalçın, A. (2019). Sosyal baltalama ve çalışan performansı ilişkisinde iş stresi ve duygusal tükenmişliğin rolü, Selçuk Üniversitesi Sosyal Bilimler Enstitüsü Dergisi, 41, 1-15.

Ünler Öz, E. (2007). Duygusal emek davranışlarının çalışanların iş sonuçlarına etkisi, Beta Yayınevi, 1. Basım, İstanbul, 88.

Wang, X., Wang, G. ve Hou, W.C. (2016). Effects of emotional labor and adaptive selling behavior on job performance, Social Behavior and Personality: An International Journal, 44(5), 801-814.

Witte, K. ve Allen, M. (2000). A meta-analysis of fear appeals: 1mplications for effective public health campaigns, Health Education \& Behavior, 27(5), 591-615.

Yakut, E., Kuru, Ö. ve Güngör, Y. (2020). Sağlık personelinin covid-19 korkusu ile tükenmişliği arasındaki ilişkide aşırı iş yükü ve algılanan sosyal desteğin etkisinin yapısal eşitlik modeliyle belirlenmesi, Ekev Akademi Dergisi, 83, 241-262.

Yanarates, E. (2020). An overall evaluation of the covid-19 pandemic, Social Scientific Centered Issues, 2(1), 2433.

Yang, S.B. ve Guy, M.E. (2015). Gender effects on emotional labor in seoul metropolitan area, Public Personnel Management, 44(1), 3-24.

Yetgin, M.A. (2020). Koronavirüsün Borsa İstanbul'a etkisi üzerine bir araştırma ve stratejik pandemi yönetimi, Finans Ekonomi ve Sosyal Araştırmalar Dergisi, 5(2), 324-335.

Yıldırımvuran, S., Milanlığlu, U.K. ve Çakan, S. (2020). Covid-19 pandemi sürecinin Türk Yarg1 Sistemine etkileri, Türk Kamu Yönetimi Dergisi, 1(1), 47-54.

Yıldız, S.M. (2015). Lider-üye etkileşimi, işyerinde mobbing ve mesleki tükenmişlik ilişkisi, Detay Yayıncılık, 144.

Yılmaz, G.Y. ve Günay, G. (2020). Presenteeism ve iş stresinin çalışan performansına etkisi: tekstil sektöründe bir uygulama, Social Sciences Research Journal, 9(1), 91-106.

Yurdakul, G., Çelenk, A., Deveci, M. ve Durukan, T. (2020). Üretim ve hizmet sektörlerinin covid-19 süreci ve sonrasındaki geleceği üzerine bir değerlendirme, Gaziantep University Journal of Social Sciences, Special Issue, 212-229. 